\title{
Molecular determinants of the adrenal gland functioning related to stress-sensitive hypertension in ISIAH rats
}

\author{
Larisa A. Fedoseeva', Leonid O. Klimov', Nikita I. Ershov', Yury V. Alexandrovich', Vadim M. Efimov,2 \\ Arcady L. Markel ${ }^{1,2}$ and Olga E. Redina ${ }^{1 *}$
}

From The International Conference on Bioinformatics of Genome Regulation and StructurelSystems Biology (BGRSISB-2016) Novosibirsk, Russia. 29 August-2 September 2016

\begin{abstract}
Background: The adrenals are known as an important link in pathogenesis of arterial hypertensive disease. The study was directed to the adrenal transcriptome analysis in ISIAH rats with stress-sensitive arterial hypertension and predominant involvement in pathogenesis of the hypothalamic-pituitary-adrenal and sympathoadrenal systems.

Results: The RNA-Seq approach was used to perform the comparative adrenal transcriptome profiling in hypertensive ISIAH and normotensive WAG rats. Multiple differentially expressed genes (DEGs) related to different biological processes and metabolic pathways were detected.

The discussion of the results helped to prioritize the several DEGs as the promising candidates for further studies of the genetic background underlying the stress-sensitive hypertension development in the ISIAH rats. Two of these were transcription factor genes (Nr4a3 and Ppard), which may be related to the predominant activation of the sympathetic-adrenal medullary axis in ISIAH rats. The other genes are known as associated with hypertension and were defined in the current study as DEGs making the most significant contribution to the inter-strain differences. Four of them (Avpr1a, Hsd11b2, Agt, Ephx2) may provoke the hypertension development, and Mpo may contribute to insulin resistance and inflammation in the ISIAH rats.

Conclusions: The study strongly highlighted the complex nature of the pathogenesis of stress-sensitive hypertension. The data obtained may be useful for identifying the common molecular determinants in different animal models of arterial hypertension, which may be potentially used as therapeutic targets for pharmacological intervention.
\end{abstract}

Keywords: Stress-sensitive hypertension, Adrenal gland, Transcriptional profiling, RNA-Seq, PLS-DA, ISIAH rats

\section{Background}

The adrenal gland is known as a key organ playing an important role in the blood pressure regulation and hypertension development. The adrenal gland produces corticosteroid hormones and catecholamines that regulate a complex set of vital organismic functions including the stress control, water and sodium balance, cardiovascular system and the blood pressure (BP) level

\footnotetext{
*Correspondence: oredina@ngs.ru

${ }^{1}$ Institute of Cytology and Genetics, Siberian Branch of Russian Academy of

Sciences, Novosibirsk, Russian Federation

Full list of author information is available at the end of the article
}

$[1,2]$. That's why the adrenal gland is an object of choice in a number of studies directed to elucidate the complex nature of hypertensive disease development or neuroendocrine profile related to stress response [3-5].

Different animal models of arterial hypertension help to analyze the transcriptome of the adrenal glands and to uncover common genetic mechanisms of hypertension across mammalian species that might, therefore, be pertinent to human hypertension too $[3,4,6]$.

The ISIAH rat strain is a model of stress-sensitive arterial hypertension with predominant involvement of the neuroendocrine hypothalamic-pituitary-adrenocortical 
(HPA) and sympathetic adrenal systems (SAS) in pathogenesis of hypertension [7-9]. The peripheral plasma aldosterone concentration and secretion rates of corticosterone, 11-dehydrocorticosterone and deoxycorticosterone measured by the adrenal vein cannulation were significantly higher in the ISIAH rats as compared to control WAG rats [10]. The sympathetic adrenal medullary function assessed by measurement of the adrenal catecholamine content showed decreased concentrations of dopamine and norepinephrine, but significantly enhanced level of epinephrine in the adrenals of ISIAH rats [9]. It was suggested that the genetically determined enhanced stress responsiveness and hypertension development in ISIAH rats may be a result of the specificity of its adrenal gland function [10].

The differences in the transcription activity of several genes measured in the adrenal glands of hypertensive ISIAH and control WAG rats $[9,10]$ demonstrated that the selection of the ISIAH rat strain for the enhanced responsiveness to mild emotional stress could lead to accumulation of the genetic changes which may affect the hypertension development.

The goal of the current study was to compare the full transcriptome profiles of the adrenal glands from hypertensive ISIAH and normotensive WAG rats in order to identify the main pathways involved in the differences of their adrenal gland functions, and to define the differentially expressed genes (DEGs) which could make the largest contribution to the stress-sensitive hypertension development.

The current study of the comparative transcriptome profiling of the adrenal glands in hypertensive ISIAH and control WAG rats resulted in the detection of multiple DEGs related to different biological processes and metabolic pathways. The use of the partial-least squares discriminant analysis (PLS-DA) helped to reveal the top 10 DEGs associated with hypertension and making the most significant contribution to the inter-strain differences. Several of these DEGs may be considered as potential candidates for further studies directed to better understanding the mechanisms of hypertension development in the ISIAH rats.

\section{Results}

Altogether, 12367 genes were defined as expressed in adrenal glands of ISIAH and WAG rats and were used in comparative expression analysis, which revealed 1113 DEGs. The complete listing of DEGs is given in Additional file 1. The hierarchical clustering based on Euclidean distance is shown in Additional file 2. More than half of the DEGs (619 genes, i.e., 55.6\%) were upregulated in ISIAH rats.

The expression of 19 genes was detected in adrenal gland of only one rat strain (Additional file 3). Three of these genes (Crp, C-reactive protein, pentraxin-related; Fabp1, fatty acid binding protein 1, liver; Ucp1, uncoupling protein 1 (mitochondrial, proton carrier)) are known as related to hypertension development. Their expression was detected in adrenal gland of ISIAH rats but not in the WAG.

Altogether, the study revealed 76 DEGs annotated in Rat Genome Database (RGD) as related to hypertension (Table 1). Most of these genes (71.1\%) were upregulated in hypertensive adrenal glands. Twenty three genes of those listed in Table 1 are known as associated with insulin resistance. Almost all of them (20 out of 23 genes) were upregulated in adrenals from ISIAH rats.

Many of DEGs (166 genes) found in the current study are known as related to the metabolic diseases including hypercholesterolemia, hyperglycemia, hyperlipidemia, different types of hyperlipoproteinemias, and insulin resistance (Table 2).

Sixty one transcription factor genes were differentially expressed in ISIAH and WAG adrenal glands (Table 3). Three of them are currently known as associated with hypertension development and 8 genes are referred to in RGD as related to metabolic diseases.

Gene Ontology (GO) terms for biological processes found to be significantly enriched are represented in Additional file 4. The groups of DEGs, which might be important for the development of the stress-sensitive hypertension, are given in bold in the file. The main groups are given in Fig. 1. The subgroups describing the specificity of the processes shown in Fig. 1 are represented in Additional file 5. The detailed information for genes in these groups is given in Additional file 6.

The most abundant group described by GO term 'response to stimulus' consisted of groups related to response to different stimuli - external stimulus, endogenous (hormone) stimulus, and stress, which were found to be among the most significantly enriched GO terms. The group of DEGs labelled 'response to hormone stimulus', consisted of subgroups of DEGs related to response to steroid hormone stimulus (and particularly to corticosteroid stimulus), response to growth hormone, and insulin stimuli. The response to stress was specified by the group of genes related to response to oxygen levels. Almost all genes (25 out of 27 ) in this group were related to response to hypoxia.

Several groups of DEGs related to BP control were found. These were: regulation of body fluid levels, blood circulation, blood coagulation, regulation of BP, regulation of angiogenesis and blood vessel size, regulation of smooth muscle cell proliferation and contraction.

Several other processes, which may play an important role in stress-sensitive hypertension development in ISIAH rats were: regulation of catecholamine secretion, glucose homeostasis, regulation of insulin-like growth 
Table 1 Genes differentially expressed in ISIAH and WAG adrenal glands and referred to in Rat Genome Database as associated with hypertension

\begin{tabular}{|c|c|c|c|}
\hline Gene symbol & Gene_ID & $\begin{array}{l}\log 2 \\
\text { (fold_change) ISIAH/WAG }\end{array}$ & Gene definition \\
\hline Ada & 24165 & 0.75 & adenosine deaminase \\
\hline Adipoq $^{a}$ & 246253 & 1.10 & $\begin{array}{l}\text { adiponectin, } \mathrm{C} 1 \mathrm{Q} \text { and collagen } \\
\text { domain containing }\end{array}$ \\
\hline$A d r b 3^{a}$ & 25645 & 2.44 & adrenergic, beta-3-, receptor \\
\hline $\mathrm{Agt}^{\mathrm{a}}$ & 24179 & 2.28 & $\begin{array}{l}\text { angiotensinogen (serpin peptidase } \\
\text { inhibitor, clade A, member 8) }\end{array}$ \\
\hline Alas1 & 65155 & 0.75 & aminolevulinate, delta-, synthase 1 \\
\hline Alox5 & 25290 & -0.83 & arachidonate 5-lipoxygenase \\
\hline Anxa3 & 25291 & 0.69 & annexin $\mathrm{A} 3$ \\
\hline Aqp 1 & 25240 & -0.49 & aquaporin 1 \\
\hline $\operatorname{Atp} 1 a 2^{a}$ & 24212 & 1.26 & $\begin{array}{l}\text { ATPase, } \mathrm{Na}+/ \mathrm{K}+\text { transporting, alpha } 2 \\
\text { polypeptide }\end{array}$ \\
\hline Avpria & 25107 & 1.12 & arginine vasopressin receptor $1 \mathrm{~A}$ \\
\hline$B c h e^{a}$ & 65036 & 1.32 & butyrylcholinesterase \\
\hline$C 1 q b$ & 29687 & 0.61 & $\begin{array}{l}\text { complement component 1, q } \\
\text { subcomponent, B chain }\end{array}$ \\
\hline$C 3^{\mathrm{a}}$ & 24232 & 2.06 & complement component 3 \\
\hline$C d 36^{\mathrm{a}}$ & 29184 & 1.04 & CD36 molecule (thrombospondin receptor) \\
\hline$C d k n 2 b$ & 25164 & -0.85 & $\begin{array}{l}\text { cyclin-dependent kinase inhibitor } 2 B \\
\text { (p15, inhibits CDK4) }\end{array}$ \\
\hline Cdo 1 & 81718 & -1.20 & cysteine dioxygenase, type I \\
\hline Cfh & 155012 & 0.76 & complement factor $\mathrm{H}$ \\
\hline Collar & 29393 & 0.80 & collagen, type I, alpha 1 \\
\hline $\mathrm{Crp}^{\mathrm{a}}$ & 25419 & detected only in ISIAH rats & C-reactive protein, pentraxin-related \\
\hline $\mathrm{C} \times 3 \mathrm{cr} 1$ & 171056 & 0.75 & chemokine (C-X3-C motif) receptor 1 \\
\hline Cxcl10 & 245920 & -1.90 & chemokine (C-X-C motif) ligand 10 \\
\hline$C y b a^{a}$ & 79129 & 0.68 & cytochrome b-245, alpha polypeptide \\
\hline Dusp 1 & 114856 & -0.94 & dual specificity phosphatase 1 \\
\hline Ednrb & 50672 & 0.82 & endothelin receptor type B \\
\hline Egr1 & 24330 & -0.92 & early growth response 1 \\
\hline Entpd2 & 64467 & 0.84 & $\begin{array}{l}\text { ectonucleoside triphosphate } \\
\text { diphosphohydrolase } 2\end{array}$ \\
\hline$E p h \times 2^{a}$ & 65030 & 4.37 & epoxide hydrolase 2, cytoplasmic \\
\hline$F 2 r$ & 25439 & 0.53 & coagulation factor II (thrombin receptor \\
\hline F5 & 304929 & 0.62 & coagulation factor $\mathrm{V}$ (proaccelerin, labile factor) \\
\hline Fabpl & 24360 & detected only in ISIAH rats & fatty acid binding protein 1 , liver \\
\hline Fas & 246097 & -0.80 & Fas (TNF receptor superfamily, member 6) \\
\hline Fbn1 & 83727 & 0.69 & fibrillin 1 \\
\hline Fmo3 & 84493 & 0.57 & flavin containing monooxygenase 3 \\
\hline$F n 1$ & 25661 & 0.76 & fibronectin 1 \\
\hline Gabbr1 & 81657 & 1.11 & gamma-aminobutyric acid (GABA) B receptor 1 \\
\hline Gstm2 & 24424 & -0.60 & glutathione S-transferase mu 2 \\
\hline Gstp1 & 24426 & -0.53 & glutathione S-transferase pi 1 \\
\hline Hdac4 & 363287 & 0.73 & histone deacetylase 4 \\
\hline Hmgbl 1 & 25459 & -0.84 & high mobility group box 1 \\
\hline
\end{tabular}


Table 1 Genes differentially expressed in ISIAH and WAG adrenal glands and referred to in Rat Genome Database as associated with hypertension (Continued)

\begin{tabular}{|c|c|c|c|}
\hline $\mathrm{Hmgcr}^{\mathrm{a}}$ & 25675 & 0.63 & $\begin{array}{l}\text { 3-hydroxy-3-methylglutaryl-CoA } \\
\text { reductase }\end{array}$ \\
\hline $\mathrm{Hmox}^{\mathrm{a}}$ & 24451 & -0.69 & heme oxygenase (decycling) 1 \\
\hline$H p^{a}$ & 24464 & 1.10 & haptoglobin \\
\hline Hsd11b2 & 25117 & -1.47 & hydroxysteroid 11-beta dehydrogenase 2 \\
\hline Hyal1 & 367166 & 0.49 & hyaluronoglucosaminidase 1 \\
\hline lgfi & 24482 & -2.12 & insulin-like growth factor 1 \\
\hline $\operatorname{ltgav}{ }^{a}$ & 296456 & -0.58 & integrin, alpha $\mathrm{V}$ \\
\hline Lox/1 & 315714 & 0.50 & lysyl oxidase-like 1 \\
\hline$\left.L p\right|^{a}$ & 24539 & 0.52 & lipoprotein lipase \\
\hline Mpo & 303413 & 4.46 & myeloperoxidase \\
\hline Nov & 81526 & -0.88 & nephroblastoma overexpressed gene \\
\hline Pik3r1 ${ }^{\mathrm{a}}$ & 25513 & 0.50 & $\begin{array}{l}\text { phosphoinositide-3-kinase, regulatory } \\
\text { subunit } 1 \text { (alpha) }\end{array}$ \\
\hline Postn & 361945 & 1.30 & periostin, osteoblast specific factor \\
\hline Pparg $^{a}$ & 25664 & 1.01 & $\begin{array}{l}\text { peroxisome proliferator-activated } \\
\text { receptor gamma }\end{array}$ \\
\hline $\operatorname{Prkcb}^{\mathrm{a}}$ & 25023 & 0.90 & protein kinase $C$, beta \\
\hline $\operatorname{Retn}^{\mathrm{a}}$ & 246250 & 2.26 & resistin \\
\hline Rgs5 & 54294 & -0.85 & regulator of G-protein signaling 5 \\
\hline$R T 1-B a$ & 309621 & 0.49 & RT1 class II, locus Ba \\
\hline$R T 1-D b 1$ & 294270 & 0.91 & RT1 class II, locus Db1 \\
\hline s100b & 25742 & -1.72 & S100 calcium binding protein B \\
\hline Serpina $1^{a}$ & 24648 & 0.77 & $\begin{array}{l}\text { serpin peptidase inhibitor, clade A } \\
\text { (alpha-1 antiproteinase, antitrypsin, member } 1\end{array}$ \\
\hline Serpine $1^{a}$ & 24617 & -2.04 & $\begin{array}{l}\text { serpin peptidase inhibitor, clade E } \\
\text { (nexin, plasminogen activator } \\
\text { inhibitor type 1), member } 1\end{array}$ \\
\hline Serpine2 & 29366 & 2.19 & $\begin{array}{l}\text { serpin peptidase inhibitor, } \\
\text { clade } \mathrm{E} \text {, member } 2\end{array}$ \\
\hline Slc4a4 & 84484 & 0.96 & $\begin{array}{l}\text { solute carrier family } 4 \text {, sodium bicarbonate } \\
\text { cotransporter, member } 4\end{array}$ \\
\hline Slc8a1 & 29715 & 0.58 & $\begin{array}{l}\text { solute carrier family } 8 \text { (sodium/calcium } \\
\text { exchanger), member } 1\end{array}$ \\
\hline Slc9a3 & 24784 & 4.24 & $\begin{array}{l}\text { solute carrier family } 9 \text { (sodium/hydrogen } \\
\text { exchanger), member } 3\end{array}$ \\
\hline Sod2 & 24787 & 0.75 & superoxide dismutase 2 , mitochondrial \\
\hline Spp1 & 25353 & -0.56 & secreted phosphoprotein 1 \\
\hline Tacr 2 & 25007 & 0.84 & tachykinin receptor 2 \\
\hline Tap 1 & 24811 & 0.84 & transporter 1, ATP-binding cassette, sub-family B (MDR/TAP) \\
\hline Tek & 89804 & 0.49 & TEK tyrosine kinase, endothelial \\
\hline Tnc & 116640 & 1.74 & tenascin C \\
\hline Trpc6 & 89823 & 0.85 & transient receptor potential cation channel, subfamily C, member 6 \\
\hline$U c p 1^{a}$ & 24860 & detected only in ISIAH rats & uncoupling protein 1 (mitochondrial, proton carrier) \\
\hline Vcam $1^{a}$ & 25361 & 0.78 & vascular cell adhesion molecule 1 \\
\hline Vip & 117064 & -1.57 & vasoactive intestinal peptide \\
\hline$x d h$ & 497811 & -0.88 & xanthine dehydrogenase \\
\hline
\end{tabular}

a - genes associated with insulin resistance; ISIAH and WAG - rat strains used in the study 
Table 2 Genes differentially expressed in ISIAH and WAG adrenal glands and referred to in Rat Genome Database as associated with metabolic diseases

\begin{tabular}{|c|c|c|c|}
\hline Gene symbol & Gene_ID & $\begin{array}{l}\text { log2 } \\
\text { (fold_change) ISIAH/WAG }\end{array}$ & Gene definition \\
\hline$A b c a 1^{\text {a b d e }}$ & 313210 & 1.12 & $\begin{array}{l}\text { ATP-binding cassette, subfamily A } \\
(A B C 1) \text {, member } 1\end{array}$ \\
\hline Abcg2 & 312382 & 1.09 & $\begin{array}{l}\text { ATP-binding cassette, subfamily } G \\
\text { (WHITE), member } 2\end{array}$ \\
\hline$A c a c b^{a}$ & 116719 & 0.98 & acetyl-CoA carboxylase beta \\
\hline Acad9 & 294973 & 0.63 & acyl-CoA dehydrogenase family, member 9 \\
\hline Acadsb & 25618 & -0.71 & acyl-CoA dehydrogenase, short/branched chain \\
\hline Acot2 & 192272 & -0.55 & acyl-CoA thioesterase 2) \\
\hline Acp5 & 25732 & -1.54 & acid phosphatase 5 , tartrate resistant \\
\hline$A d a^{c}$ & 24165 & 0.75 & adenosine deaminase \\
\hline Adipoq $^{\text {a d }}$ & 246253 & 1.10 & $\begin{array}{l}\text { adiponectin, } \mathrm{C} 1 \mathrm{Q} \text { and collagen } \\
\text { domain containing }\end{array}$ \\
\hline $\operatorname{Adrb}^{\mathrm{a}}$ & 25645 & 2.44 & adrenergic, beta-3-, receptor \\
\hline Adss/1 & 684425 & 0.91 & adenylosuccinate synthase like 1 \\
\hline Agt $^{\mathrm{a}}$ & 24179 & 2.28 & $\begin{array}{l}\text { angiotensinogen (serpin peptidase } \\
\text { inhibitor, clade A, member 8) }\end{array}$ \\
\hline Ahsg $g^{\text {a }}$ & 25373 & detected only in ISIAH rats & alpha-2-HS-glycoprotein \\
\hline Aif1 & 29427 & 0.95 & allograft inflammatory factor 1 \\
\hline$A k 1$ & 24183 & -0.72 & adenylate kinase 1 \\
\hline Alas1 & 65155 & 0.75 & aminolevulinate, delta-, synthase 1 \\
\hline$A /\left.p\right|^{a b d}$ & 25586 & -1.32 & alkaline phosphatase, liver/bone/kidney \\
\hline Anxa5 & 25673 & -0.97 & annexin $\mathrm{A} 5$ \\
\hline Aox1 & 54349 & 1.74 & aldehyde oxidase 1 \\
\hline$A p o c 1^{d}$ & 25292 & -0.90 & apolipoprotein C-I \\
\hline Aqp 1 & 25240 & -0.49 & aquaporin 1 \\
\hline Arsb & 25227 & -0.49 & arylsulfatase B \\
\hline Aspa & 79251 & 1.01 & aspartoacylase \\
\hline $\operatorname{Atp} 1 a 2^{a}$ & 24212 & 1.26 & $\begin{array}{l}\text { ATPase, } \mathrm{Na}+/ \mathrm{K}+\text { transporting, } \\
\text { alpha } 2 \text { polypeptide }\end{array}$ \\
\hline$B c h e^{a d}$ & 65036 & 1.32 & butyrylcholinesterase \\
\hline Clqa & 298566 & 0.77 & $\begin{array}{l}\text { complement component 1, q } \\
\text { subcomponent, A chain }\end{array}$ \\
\hline$C 3^{\mathrm{a}}$ & 24232 & 2.06 & complement component 3 \\
\hline Cartpt & 29131 & -3.09 & CART prepropeptide \\
\hline Casq1 & 686019 & -1.87 & calsequestrin 1 (fast-twitch, skeletal muscle) \\
\hline Casq2 & 29209 & 2.32 & calsequestrin 2 (cardiac muscle) \\
\hline $\mathrm{CCl} 11^{\mathrm{C}}$ & 29397 & 1.41 & chemokine (C-C motif) ligand 11 \\
\hline$C d 36^{\mathrm{a}}$ & 29184 & 1.04 & CD36 molecule (thrombospondin receptor) \\
\hline$C f b$ & 294257 & 0.65 & complement factor B \\
\hline Cfh & 155012 & 0.76 & complement factor $\mathrm{H}$ \\
\hline Chek $^{\mathrm{a}}$ & 114212 & -0.92 & checkpoint kinase 2 \\
\hline Cidec & 500292 & 1.65 & cell death-inducing DFFA-like effector $c$ \\
\hline Colla1 & 29393 & 0.80 & collagen, type I, alpha 1 \\
\hline Cpox & 304024 & 0.50 & coproporphyrinogen oxidase \\
\hline$C r p^{\text {a d }}$ & 25419 & detected only in ISIAH rats & C-reactive protein, pentraxin-related \\
\hline
\end{tabular}


Table 2 Genes differentially expressed in ISIAH and WAG adrenal glands and referred to in Rat Genome Database as associated with metabolic diseases (Continued)

\begin{tabular}{|c|c|c|c|}
\hline $\mathrm{C} \times 3 \mathrm{Cr} 1$ & 171056 & 0.75 & chemokine (C-X3-C motif) receptor 1 \\
\hline Cxcl10 & 245920 & -1.90 & chemokine (C-X-C motif) ligand 10 \\
\hline $\mathrm{CxCl12}$ & 24772 & 0.91 & chemokine (C-X-C motif) ligand 12 \\
\hline$C y b a^{a}$ & 79129 & 0.68 & cytochrome b-245, alpha polypeptide \\
\hline Cyp2e1 & 25086 & 1.91 & $\begin{array}{l}\text { cytochrome P450, family } 2 \text {, subfamily } \\
\text { e, polypeptide } 1\end{array}$ \\
\hline Dab2 & 79128 & 0.79 & disabled homolog 2 (Drosophila) \\
\hline Dcaf12/1 & 313296 & -1.59 & DDB1 and CUL4 associated factor 12-like 1 \\
\hline Den & 29139 & 0.54 & decorin \\
\hline Dgatr $^{\text {ad }}$ & 84497 & 0.63 & diacylglycerol O-acyltransferase 1 \\
\hline Dusp $1^{c}$ & 114856 & -0.94 & dual specificity phosphatase 1 \\
\hline Ednrb & 50672 & 0.82 & endothelin receptor type B \\
\hline Ehhadh & 171142 & 2.01 & $\begin{array}{l}\text { enoyl-CoA, hydratase/3-hydroxyacyl } \\
\text { CoA dehydrogenase }\end{array}$ \\
\hline Entpd5 & 314312 & -1.00 & $\begin{array}{l}\text { ectonucleoside triphosphate } \\
\text { diphosphohydrolase } 5\end{array}$ \\
\hline Eph $\times 2^{\mathrm{a}} \mathrm{b} \mathrm{d}$ e & 65030 & 4.37 & epoxide hydrolase 2, cytoplasmic \\
\hline Ercc4 & 304719 & -1.12 & $\begin{array}{l}\text { excision repair cross-complementing rodent repair } \\
\text { deficiency, complementation group } 4\end{array}$ \\
\hline F13a1 & 60327 & 1.00 & coagulation factor XIII, A1 polypeptide \\
\hline Fabp $4^{a}$ & 79451 & 1.61 & fatty acid binding protein 4 , adipocyte \\
\hline Fam111a & 499322 & 3.85 & family with sequence similarity 111 , member A \\
\hline Fam126a & 499975 & -0.72 & family with sequence similarity 126 , member A \\
\hline Fas & 246097 & -0.80 & Fas (TNF receptor superfamily, member 6) \\
\hline Fbn1 & 83727 & 0.69 & fibrillin 1 \\
\hline Fgb & 24366 & detected only in ISIAH rats & fibrinogen beta chain \\
\hline Fgg & 24367 & 1.47 & fibrinogen gamma chain \\
\hline Fmo3 & 84493 & 0.57 & flavin containing monooxygenase 3 \\
\hline Fn1 & 25661 & 0.76 & fibronectin 1 \\
\hline Foxol $1^{a}$ & 84482 & -0.86 & forkhead box $\mathrm{O} 1$ \\
\hline Fus & 317385 & 0.65 & fused in sarcoma \\
\hline Gabbr1 & 81657 & 1.11 & gamma-aminobutyric acid (GABA) B receptor 1 \\
\hline Galns & 292073 & 0.81 & galactosamine ( $\mathrm{N}$-acetyl)-6-sulfate sulfatase \\
\hline Gas6 & 58935 & 0.50 & growth arrest specific 6 \\
\hline Gatm & 81660 & -1.26 & $\begin{array}{l}\text { glycine amidinotransferase } \\
\text { (L-arginine:glycine amidinotransferase) }\end{array}$ \\
\hline Gcgr & 24953 & 1.02 & glucagon receptor \\
\hline Gfpt2 & 360518 & 1.51 & glutamine-fructose-6-phosphate transaminase 2 \\
\hline Gk & 79223 & -0.63 & glycerol kinase \\
\hline Glrx & 64045 & 0.66 & glutaredoxin (thioltransferase) \\
\hline Grial & 50592 & -2.39 & glutamate receptor, ionotropic, AMPA 1 \\
\hline Gstp1 & 24426 & -0.53 & glutathione S-transferase pi 1 \\
\hline Hap 1 & 29430 & -0.61 & huntingtin-associated protein 1 \\
\hline Hdac4 & 363287 & 0.73 & histone deacetylase 4 \\
\hline Hmgbl & 25459 & -0.84 & high mobility group box 1 \\
\hline$H m g c r^{a} b d$ & 25675 & 0.63 & 3-hydroxy-3-methylglutaryl-CoA reductase \\
\hline
\end{tabular}


Table 2 Genes differentially expressed in ISIAH and WAG adrenal glands and referred to in Rat Genome Database as associated with metabolic diseases (Continued)

\begin{tabular}{|c|c|c|c|}
\hline$\overline{H m o x 1^{\mathrm{a}}}$ & 24451 & -0.69 & heme oxygenase (decycling) 1 \\
\hline$H p^{a b c d}$ & 24464 & 1.10 & haptoglobin \\
\hline Hsd11b2 & 25117 & -1.47 & hydroxysteroid 11-beta dehydrogenase 2 \\
\hline Hspala & 24472 & 0.70 & heat shock $70 \mathrm{kD}$ protein $1 \mathrm{~A}$ \\
\hline Hyal1 & 367166 & 0.49 & hyaluronoglucosaminidase 1 \\
\hline Ifih1 & 499801 & 0.69 & interferon induced with helicase $\mathrm{C}$ domain 1 \\
\hline $\lg f 1$ & 24482 & -2.12 & insulin-like growth factor 1 \\
\hline $111 r 1$ & 25663 & 0.86 & interleukin 1 receptor, type I \\
\hline Iscu & 288740 & -0.65 & iron-sulfur cluster scaffold homolog (E, coli) \\
\hline $\operatorname{lsg} 15$ & 298693 & 0.95 & ISG15 ubiquitin-like modifier \\
\hline $\operatorname{ltga} 2$ & 170921 & -1.29 & integrin, alpha 2 \\
\hline $\operatorname{ltg} a v^{a c}$ & 296456 & -0.58 & integrin, alpha $V$ \\
\hline$J a k 2^{c}$ & 24514 & -0.63 & Janus kinase 2 \\
\hline Jak3 & 25326 & -0.57 & Janus kinase 3 \\
\hline Jam3 & 315509 & 0.58 & junctional adhesion molecule 3 \\
\hline Kcnmal & 83731 & 0.77 & $\begin{array}{l}\text { potassium large conductance calcium-activated } \\
\text { channel, subfamily M, alpha member } 1\end{array}$ \\
\hline Lcat $^{\mathrm{d}}$ & 24530 & 0.97 & lecithin cholesterol acyltransferase \\
\hline$L d l r^{b} d$ e & 300438 & 0.93 & low density lipoprotein receptor \\
\hline LOC689064 & 689064 & 2.02 & beta-globin \\
\hline Loxl1 & 315714 & 0.50 & lysyl oxidase-like 1 \\
\hline$\left.L p\right|^{a d \mathrm{e}}$ & 24539 & 0.52 & lipoprotein lipase \\
\hline Lrrk2 & 300160 & 1.12 & leucine-rich repeat kinase 2 \\
\hline Lyz2 & 25211 & 0.80 & lysozyme 2 \\
\hline Mgp & 25333 & 0.48 & matrix Gla protein \\
\hline Mpo & 303413 & 4.46 & myeloperoxidase \\
\hline Mpz & 24564 & 1.69 & myelin protein zero \\
\hline$M+2 A$ & 689415 & -1.05 & metallothionein 2A \\
\hline Myeov2 & 681389 & -0.53 & myeloma overexpressed 2 \\
\hline Myo5b & 25132 & -1.13 & myosin Vb \\
\hline Ndufaf2 & 361894 & -0.85 & $\begin{array}{l}\text { NADH dehydrogenase (ubiquinone) } \\
1 \text { alpha subcomplex, assembly factor } 2\end{array}$ \\
\hline Nefh & 24587 & 1.44 & neurofilament, heavy polypeptide \\
\hline Nefm & 24588 & -0.79 & neurofilament, medium polypeptide \\
\hline Nr1d1 & 252917 & -0.57 & nuclear receptor subfamily 1 , group D, member 1 \\
\hline Nucb2 & 59295 & -0.64 & nucleobindin 2 \\
\hline Oxct1 & 690163 & -0.86 & 3-oxoacid CoA transferase 1 \\
\hline P2ry2 & 29597 & -1.31 & purinergic receptor P2Y, G-protein coupled, 2 \\
\hline Pah & 24616 & -0.86 & phenylalanine hydroxylase \\
\hline$P c k 1^{c}$ & 362282 & 3.83 & phosphoenolpyruvate carboxykinase 1 (soluble) \\
\hline Pfkfbl & 24638 & 1.58 & 6-phosphofructo-2-kinase/fructose-2,6-biphosphatase 1 \\
\hline Phgdh & 58835 & -1.93 & phosphoglycerate dehydrogenase \\
\hline$P i k 3 r r^{\mathrm{a}}$ & 25513 & 0.50 & $\begin{array}{l}\text { phosphoinositide-3-kinase, regulatory } \\
\text { subunit } 1 \text { (alpha) }\end{array}$ \\
\hline Pla2g $7^{\mathrm{a}}$ & 301265 & -0.97 & \\
\hline
\end{tabular}


Table 2 Genes differentially expressed in ISIAH and WAG adrenal glands and referred to in Rat Genome Database as associated with metabolic diseases (Continued)

\begin{tabular}{|c|c|c|c|}
\hline & & & $\begin{array}{l}\text { phospholipase A2, group VII (platelet-activating } \\
\text { factor acetylhydrolase, plasma) }\end{array}$ \\
\hline Plau ${ }^{d}$ & 25619 & -0.78 & plasminogen activator, urokinase \\
\hline Plin 1 & 25629 & 2.04 & perilipin 1 \\
\hline Postn & 361945 & 1.30 & periostin, osteoblast specific factor \\
\hline Ppard $^{\mathrm{a}}$ & 25682 & 0.56 & peroxisome proliferator-activated receptor delta \\
\hline Pparg a d & 25664 & 1.01 & peroxisome proliferator-activated receptor gamma \\
\hline Ppt1 & 29411 & 0.48 & palmitoyl-protein thioesterase 1 \\
\hline Prkcb $b^{\text {a }}$ & 25023 & 0.90 & protein kinase $C$, beta \\
\hline Psmb9 & 24967 & 0.47 & $\begin{array}{l}\text { proteasome (prosome, macropain) subunit, } \\
\text { beta type } 9 \text { (large multifunctional peptidase 2) }\end{array}$ \\
\hline Ptprn & 116660 & -0.75 & protein tyrosine phosphatase, receptor type, $\mathrm{N}$ \\
\hline Rbp4 & 25703 & 1.83 & retinol binding protein 4 , plasma \\
\hline $\operatorname{Retn}^{\mathrm{a}}$ & 246250 & 2.26 & resistin \\
\hline RGD1562200 & 363471 & 0.84 & $\begin{array}{l}\text { patatin-like phospholipase } \\
\text { domain-containing protein 4-like }\end{array}$ \\
\hline$R T 1-B a^{c}$ & 309621 & 0.49 & RT1 class II, locus Ba \\
\hline RT1-Da & 294269 & 0.80 & RT1 class II, locus Da \\
\hline$R T 1-D b 1$ & 294270 & 0.91 & RT1 class II, locus Db1 \\
\hline $5100 b$ & 25742 & -1.72 & S100 calcium binding protein B \\
\hline Scd 1 & 246074 & 2.16 & stearoyl-Coenzyme A desaturase 1 \\
\hline $\operatorname{Scn} 1 b$ & 29686 & -0.56 & sodium channel, voltage-gated, type I, beta \\
\hline Serpina $1^{a}$ & 24648 & 0.77 & $\begin{array}{l}\text { serpin peptidase inhibitor, clade A (alpha-1 antiproteinase, } \\
\text { antitrypsin, member } 1\end{array}$ \\
\hline Serpine $1^{a}$ & 24617 & -2.04 & $\begin{array}{l}\text { serpin peptidase inhibitor, clade } \mathrm{E} \text { (nexin, plasminogen } \\
\text { activator inhibitor type 1), member } 1\end{array}$ \\
\hline Slc11ar & 316519 & 0.69 & $\begin{array}{l}\text { solute carrier family } 11 \text { (proton-coupled divalent } \\
\text { metal ion transporters), member } 1\end{array}$ \\
\hline Slc16a12 & 309525 & 0.91 & $\begin{array}{l}\text { solute carrier family } 16, \text { member } 12 \\
\text { (monocarboxylic acid transporter } 12 \text { ) }\end{array}$ \\
\hline Slc4a4 & 84484 & 0.96 & $\begin{array}{l}\text { solute carrier family } 4 \text {, sodium bicarbonate } \\
\text { cotransporter, member } 4\end{array}$ \\
\hline SIC7a7 & 83509 & -0.69 & $\begin{array}{l}\text { solute carrier family } 7 \text { (amino acid transporter } \\
\text { light chain, y\%2BL system), member } 7\end{array}$ \\
\hline SIc8a1 & 29715 & 0.58 & solute carrier family 8 (sodium/calcium exchanger), member 1 \\
\hline Slc9a3 & 24784 & 4.24 & solute carrier family 9 (sodium/hydrogen exchanger), member 3 \\
\hline Sod2 & 24787 & 0.75 & superoxide dismutase 2 , mitochondrial \\
\hline Sorbs $1^{\mathrm{a}}$ & 686098 & -0.85 & sorbin and $\mathrm{SH} 3$ domain containing 1 \\
\hline Spg11 & 311372 & -0.55 & spastic paraplegia 11 (autosomal recessive) \\
\hline Spp 1 & 25353 & -0.56 & secreted phosphoprotein 1 \\
\hline Stat5b & 25126 & -0.50 & signal transducer and activator of transcription $5 \mathrm{~B}$ \\
\hline Tap 1 & 24811 & 0.84 & transporter 1, ATP-binding cassette, sub-family B (MDR/TAP) \\
\hline Thbs 1 & 445442 & 0.64 & thrombospondin 1 \\
\hline The & 116640 & 1.74 & tenascin C \\
\hline Trpc6 & 89823 & 0.85 & transient receptor potential cation channel, subfamily C, member 6 \\
\hline Ttr & 24856 & 3.93 & transthyretin \\
\hline Uchl5 & 360853 & -0.57 & ubiquitin carboxyl-terminal hydrolase L5 \\
\hline
\end{tabular}


Table 2 Genes differentially expressed in ISIAH and WAG adrenal glands and referred to in Rat Genome Database as associated with metabolic diseases (Continued)

\begin{tabular}{llll}
\hline Ucp $^{\text {a }}$ & 24860 & detected only in ISIAH rats & uncoupling protein 1 (mitochondrial, proton carrier) \\
Unc13a & 64829 & -1.01 & unc-13 homolog A (C, elegans) \\
Vcam $^{\text {a d }}$ & 25361 & 0.78 & vascular cell adhesion molecule 1 \\
Vip & 117064 & -1.57 & vasoactive intestinal peptide \\
VIdlr b d & 25696 & -0.61 & very low density lipoprotein receptor \\
Wfs 1 & 83725 & 1.77 & Wolfram syndrome 1 homolog (human) \\
Xdh & 497811 & -0.88 & xanthine dehydrogenase \\
\hline
\end{tabular}

Genes associated with: ${ }^{a}$-insulin resistance; ${ }^{b}$ - hypercholesterolemia; ${ }^{c}$ - hyperglycemia; ${ }^{d}$-hyperlipidemia; ${ }^{\text {e }}$ - hyperlipoproteinemias; ISIAH and WAG - rat strains used in the study

factor receptor signaling pathway, oxidation reduction, calcium ion homeostasis, regulation of neurological system process (regulation of synaptic plasticity).

Multiple DEGs were related to transport (transport of lipids, cholesterol, and carboxylic acid) and regulation of transport. The differences of adrenal gland functioning in hypertensive ISIAH and normotensive WAG rats were also found to be under control of many genes involved in homeostatic process, lipid metabolic process, intracellular signaling cascade, cell adhesion and extracellular matrix organization, endocytosis, apoptosis, and the regulation of these biological processes.

The immune system process and its regulation were also among the most abundant and significantly enriched groups. Multiple DEGs were associated with inflammatory and adaptive, innate, and humoral immune responses.

Among the 15 significantly enriched $(p<0.05)$ KEGG (Kyoto Encyclopedia of Genes and Genomes) pathways identified in the current study, there were several associated with the function of immune system (Additional file 7). The other were related to complement and the blood coagulation cascades, PPAR signaling pathway, ECMreceptor interaction, focal adhesion, chemokine signaling pathway, glutathione metabolism. All of these pathways contained genes associated with hypertension and metabolic diseases.

The partial-least squares discriminant analysis (PLSDA) was performed to identify the genes making the greatest impact to inter-strain differences. The constructed PLS-DA Axes maximized the distances between rats from two strains (Fig. 2), and the Pearson correlation calculated between gene expression and PLS-DA Axis 1 helped to determine the distribution of the genes along the axis representing the correlation between gene expression and PLS-DA Axis 1 (Fig. 3). The DEGs are shown in red in Fig. 3, and their polar position in the histogram assumes their contribution to the inter-strain differences. The 10 DEGs at the most polar position, which are known as associated with hypertension and showing greater than 2 fold differences in their level of transcription in the adrenal glands of ISIAH and WAG rats, were considered as the DEGs contributing the most to the inter-strain variations (Table 4). The differential transcription of these top 10 DEGs was validated by qPCR (Fig. 4). The comparison of the relative mRNA abundance between the RNA-Seq and qPCR measurements is represented in Additional file 8. The results obtained from the two methods were highly similar, with a calculated correlation coefficient of 0.99 .

\section{Discussion}

The transcriptome profiling of the adrenal glands from ISIAH and WAG rats let to identify multiple DEGs and several pathways contributing to differences between the adrenal gland functions in ISIAH rats with stresssensitive hypertension and normotensive controls.

The study revealed several genes with detected transcription in adrenal gland of only one rat strain. Three of them (Crp, Fabp1, and Ucp1), known as associated with hypertension, were expressed only in adrenal glands from hypertensive rats. However, the low levels of expression of these genes were reported in adrenals from normotensive Fischer 344 male rats, too [11]. So, the inter-strain differences in transcriptional activity of these genes shouldn't be essential for hypertension development in ISIAH rats.

The specificity of the stress-sensitive hypertension may be seen from the functional annotation of DEGs performed in Database for Annotation, Visualization and Integrated Discovery (DAVID). The analysis showed that the group of DEGs described by GO term 'response to stimulus' was one of the most abundant. This could be a priori expected for the stress-induced models of hypertension, as the adrenal gland is a component of the HPA and sympatheticadrenal medullary axes, which are both involved in neuroendocrine response to stress [12, 13]. However, in the current experiment, the rats were studied at rest condition. So, we may suggest that among the DEGs related to response to stimulus there should be those particular ones which define the predominant 
Table 3 Transcription factor genes differentially expressed in ISIAH and WAG adrenal glands

\begin{tabular}{|c|c|c|c|}
\hline Gene symbol & Gene_ID & log2 (fold_change) ISIAH/WAG & Gene definition \\
\hline Ajuba & 85265 & 1.22 & ajuba LIM protein \\
\hline Apbb1 & 29722 & 0.52 & $\begin{array}{l}\text { amyloid beta (A4) precursor protein-binding, } \\
\text { family B, member } 1 \text { (Fe65) }\end{array}$ \\
\hline Arhgap5 & 299012 & -0.58 & Rho GTPase activating protein 5 \\
\hline Bcl6 & 303836 & -1.16 & B-cell CLL/lymphoma 6 \\
\hline Cbfb & 361391 & -0.66 & core-binding factor, beta subunit \\
\hline Ccnc & 114839 & -0.59 & cyclin C \\
\hline $\mathrm{Ccn} / 2$ & 298686 & -0.72 & cyclin L2 \\
\hline Cebpa & 24252 & 0.85 & CCAAT/enhancer binding protein (C/EBP), alpha \\
\hline Cnot3 & 308311 & 0.60 & CCR4-NOT transcription complex, subunit 3 \\
\hline Creb3/1 & 362165 & 1.22 & CAMP responsive element binding protein 3-like 1 \\
\hline Csrp2 & 29317 & -0.60 & cysteine and glycine-rich protein 2 \\
\hline Dab2 & 79128 & 0.79 & disabled homolog 2 (Drosophila) \\
\hline Egr1 $^{\mathrm{a}}$ & 24330 & -0.92 & early growth response 1 \\
\hline Ets2 & 304063 & -0.83 & $\begin{array}{l}\text { v-ets erythroblastosis virus E26 } \\
\text { oncogene homolog } 2 \text { (avian) }\end{array}$ \\
\hline Etv1 & 362733 & -0.52 & ets variant 1 \\
\hline $\mathrm{Fev}$ & 246271 & -0.92 & FEV (ETS oncogene family) \\
\hline Foxol $1^{\mathrm{b}}$ & 84482 & -0.86 & forkhead box 01 \\
\hline Fus & 317385 & 0.65 & fused in sarcoma \\
\hline Grhl1 & 313993 & 1.06 & grainyhead-like 1 (Drosophila) \\
\hline Hcls1 & 288077 & 0.63 & hematopoietic cell specific Lyn substrate 1 \\
\hline $\mathrm{Hdac}^{\mathrm{a}}$ & 363287 & 0.73 & histone deacetylase 4 \\
\hline Hes1 & 29577 & -0.84 & hairy and enhancer of split 1 (Drosophila) \\
\hline HItf & 295568 & -0.58 & helicase-like transcription factor \\
\hline Ifi204 & 304988 & 1.05 & interferon activated gene 204 \\
\hline Irf7 & 293624 & 1.64 & interferon regulatory factor 7 \\
\hline Irf9 & 305896 & 0.77 & interferon regulatory factor 9 \\
\hline Junb & 24517 & -1.58 & jun B proto-oncogene \\
\hline KIhl6 & 287974 & 1.00 & kelch-like family member 6 \\
\hline Lcor & 365462 & -0.59 & ligand dependent nuclear receptor corepressor \\
\hline$L d b 3$ & 498587 & 1.30 & LIM domain binding 3 \\
\hline Mbd1 & 291439 & -0.81 & methyl-CpG binding domain protein 1 \\
\hline Mcm7 & 288532 & 0.80 & minichromosome maintenance complex component 7 \\
\hline Mlxipl & 171078 & -0.93 & MLX interacting protein-like \\
\hline Mphosph8 & 290270 & -0.86 & M-phase phosphoprotein 8 \\
\hline Nfkbil1 & 361794 & 0.62 & $\begin{array}{l}\text { nuclear factor of kappa light polypeptide gene } \\
\text { enhancer in B-cells inhibitor-like } 1\end{array}$ \\
\hline$N f x 1$ & 313166 & 0.50 & nuclear transcription factor, X-box binding 1 \\
\hline$N k \times 3-1$ & 305999 & 2.11 & NK3 homeobox 1 \\
\hline Nr1d1 & 252917 & -0.57 & nuclear receptor subfamily 1 , group D, member 1 \\
\hline $\mathrm{Nr} 4 a 3$ & 58853 & 1.20 & nuclear receptor subfamily 4, group A, member 3 \\
\hline Nrip1 & 304157 & -0.70 & nuclear receptor interacting protein 1 \\
\hline Pcaf & 301164 & -0.54 & p300/CBP-associated factor \\
\hline Pdlim3 & 114108 & 1.06 & PDZ and LIM domain 3 \\
\hline
\end{tabular}


Table 3 Transcription factor genes differentially expressed in ISIAH and WAG adrenal glands (Continued)

\begin{tabular}{|c|c|c|c|}
\hline$P m l$ & 315713 & 0.54 & promyelocytic leukemia \\
\hline Ppard $^{\mathrm{b}}$ & 25682 & 0.56 & peroxisome proliferator-activated receptor delta \\
\hline Pparga b & 25664 & 1.01 & peroxisome proliferator-activated receptor gamma \\
\hline Preb & 58842 & 0.52 & prolactin regulatory element binding \\
\hline Pric285 & 296474 & 0.50 & $\begin{array}{l}\text { peroxisomal proliferator-activated receptor A } \\
\text { interacting complex } 285\end{array}$ \\
\hline Prpf4b & 291078 & -0.58 & PRP4 pre-mRNA processing factor 4 homolog B (yeast) \\
\hline Rbm43 & 311020 & 0.80 & RNA-binding protein 43 \\
\hline Rere & 116665 & -0.57 & arginine-glutamic acid dipeptide (RE) repeats \\
\hline Smurf2 & 303614 & 0.95 & SMAD specific E3 ubiquitin protein ligase 2 \\
\hline Stat5b & 25126 & -0.50 & signal transducer and activator of transcription 5B \\
\hline Tcf3 & 171046 & 0.67 & transcription factor 3 \\
\hline Tfdp2 & 300947 & -0.78 & transcription factor Dp-2 (E2F dimerization partner 2) \\
\hline Tgfblit & 84574 & 1.11 & transforming growth factor beta 1 induced transcript 1 \\
\hline Twist2 & 59327 & 1.00 & twist homolog 2 (Drosophila) \\
\hline Vgll3 & 498038 & 1.66 & vestigial-like family member 3 \\
\hline Zbtb16 & 353227 & 1.26 & zinc finger and BTB domain containing 16 \\
\hline Zfp281 & 305083 & -0.54 & zinc finger protein 281 \\
\hline Zfp292 & 50552 & -0.53 & zinc finger protein 292 \\
\hline Zmynd12 & 313552 & -0.96 & zinc finger, MYND-type containing 12 \\
\hline
\end{tabular}

Genes associated with: ${ }^{a}$ - hypertension; ${ }^{b}$ - insulin resistance; ISIAH and WAG - rat strains used in the study

activation of the HPA and the sympathetic adrenal medullary axes in the pathogenesis of the hypertensive state in ISIAH rats selected for the enhanced BP in response to the mild emotional stress $(0.5 \mathrm{~h}$ restriction in a small wire mesh cage) $[7,9]$.
Earlier in the study of the adrenal medulla transcriptome in Sprague-Dawley rats it was reported that multiple transcription factors were upregulated in response to the acute immobilization stress [5]. In the current experiment, the group of DEGs, associated with the GO

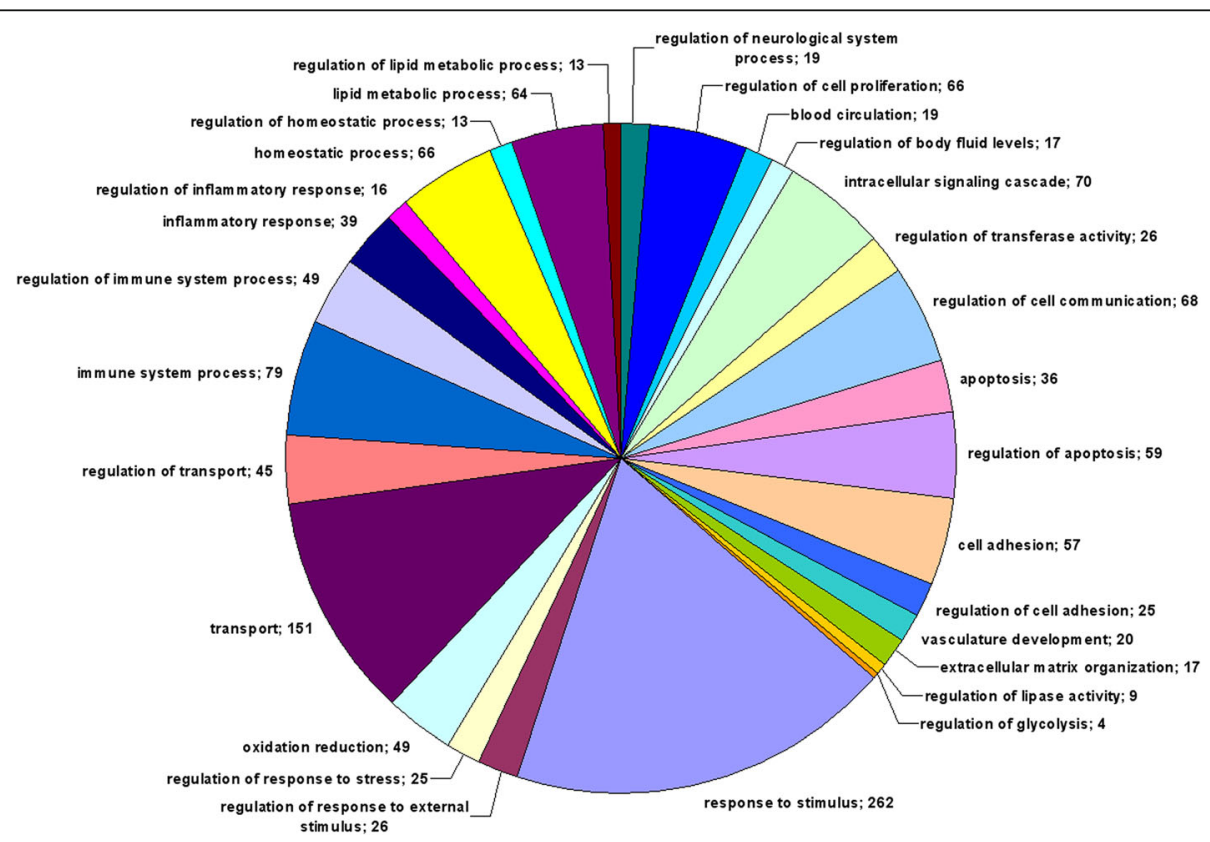

Fig. 1 The main Gene Ontology (GO) terms for biological processes. Numerals represent the number of genes in the group 


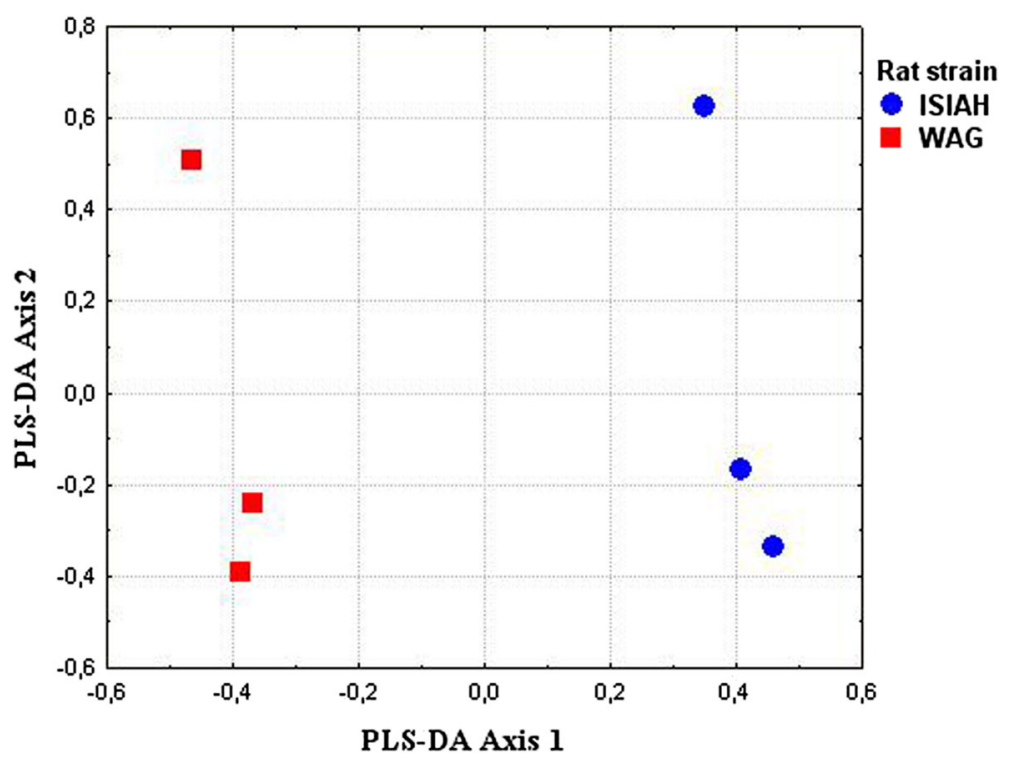

Fig. 2 Axes maximizing the distances between ISIAH and WAG rats

term 'response to stimulus' in ISIAH rats, also contained multiple transcription factor genes most of which (13 out of 21) were upregulated. In the experiment with gene transcriptional profiling after acute immobilization stress in the adrenal medulla from the Sprague-Dawley rats [5] and in the current study we found 4 common transcription factor genes (Egr1, Junb, Nr4a3, and Ppard), with Nr4a3 and Ppard being upregulated in both experiments. The orphan nuclear receptor, NOR-1 (also known as NR4A3) was reported as a target of beta-adrenergic signaling in skeletal muscles [14]. Taking all the information together, we may hypothesize that the enhanced transcriptional activity of $\mathrm{Nr} 4 \mathrm{a} 3$ may be related to the predominant activation of the sympathetic-adrenal medullary axis in ISIAH rats. To our knowledge, the role of the sympathetic nervous system in activation of Ppard has not been described up to date, however, its important role may be expected from the study of the acute immobilization stress response of the adrenal glands in Sprague-Dawley rats [5].

The adrenal medullary tissue contributes to maintain body homeostasis in stressful environment via the release of catecholamines into circulatory system in response to splanchnic nerve activation [15]. The acetylcholine released by the sympathetic splanchnic nerves activates neuronal-type nicotinic acetylcholine receptors (nAChRs) on the membrane of chromaffin cells

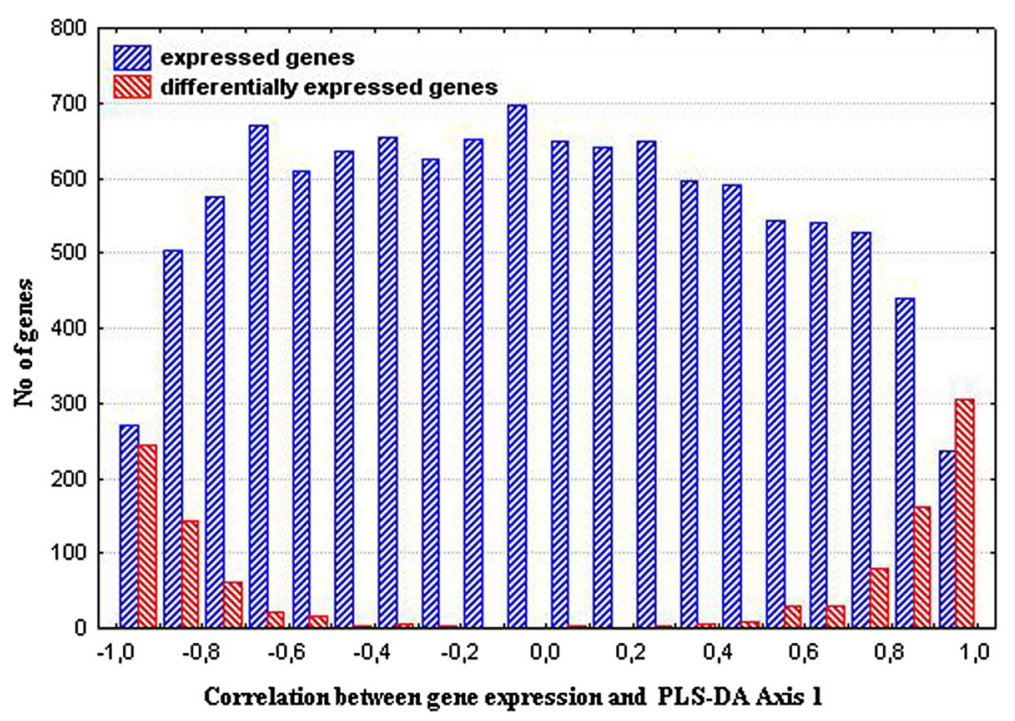

Fig. 3 The correlation between genes expression and PLS-DA Axis 1. DEGs distribution is shown in red 
Table 4 The top 10 DEGs making the most significant contribution to the inter-strain differences and associated with hypertension

\begin{tabular}{llcl}
\hline Gene symbol & Gene_ID & $\begin{array}{l}\text { log2 } \\
\text { (fold_change) ISIAH/WAG }\end{array}$ & Gene definition \\
\hline Agt & 24179 & 2.28 & angiotensinogen (serpin peptidase inhibitor, clade A, member 8) \\
Avpr1a & 25107 & 1.12 & arginine vasopressin receptor 1A \\
Ephx2 & 65030 & 4.37 & epoxide hydrolase 2, cytoplasmic \\
Gabbr1 & 81657 & 1.11 & gamma-aminobutyric acid (GABA) B receptor 1 \\
Hsd11b2 & 25117 & -1.47 & hydroxysteroid 11-beta dehydrogenase 2 \\
Igf1 & 24482 & -2.12 & insulin-like growth factor 1 \\
Mpo & 303413 & 4.46 & myeloperoxidase \\
S100b & 25742 & -1.72 & S100 calcium binding protein B \\
Serpine1 & 24617 & -2.04 & serpin peptidase inhibitor, clade E (nexin, plasminogen activator inhibitor type 1), member 1 \\
Serpine2 & 29366 & 2.19 & serpin peptidase inhibitor, clade E, member 2 \\
\hline
\end{tabular}

ISIAH and WAG - rat strains used in the study

which liberate catecholamines into the bloodstream in preparation for the fight and flight reactions [16]. In the current study several DEGs involved in the regulation of catecholamine secretion were found (Additional file 6), including Chrna4 (cholinergic receptor, nicotinic, alpha 4). However, Chrna4 was downregulated in ISIAH adrenals. Besides, one more gene in this group, Cartpt (CART prepropeptide) known as activating sympathoadrenal outflow [17], was also decreased. These findings suggest the involvement of the Chrna4 and Cartpt genes in compensatory mechanism directed to attenuate the catecholamine release by the adrenals of ISIAH rats.

The predominantly increased effectiveness of the HPA axis in the ISIAH rats may be related to the DEGs participating in response to hormonal stimuli. Most of the DEGs in this group (16 out of 25) were upregulated in the adrenal glands from ISIAH rats (Additional file 6), and about half of them are known as associated with hypertension. Three of these DEGs (Avpr1a, arginine vasopressin receptor $1 \mathrm{~A}$; $H s d 11 b 2$, hydroxysteroid 11beta dehydrogenase 2; and $I g f 1$, insulin-like growth factor 1) were reckoned among the top 10 DEGs making the most significant contribution to the inter-strain differences (Table 4).

V1a receptor (Avpr1a) plays an important role in the basal arterial BP maintenance by regulation of circulating blood volume and baroreflex sensitivity [18]. Vasopressin is a potent autocrine/paracrine regulator of mammal adrenal functions. V1a receptor is expressed both in adrenal cortex and adrenal medulla. In the adrenal cortex V1a receptor triggers both steroid secretion and cortical growth [19]. Besides, V1a receptor is present in vascular smooth muscles and is responsible for the classical vasopressor action of vasopressin [20]. The Avprla upregulation in the ISIAH adrenal glands may indicate the exaggerated effects on multiple adrenal functions in ISIAH rats.

Our previous studies confirmed the reduced activity of $11 \beta$-hydroxysteroid dehydrogenase type 2 (11 $\beta$-HSD2) in adrenal glands of ISIAH rats [21] and in peripheral blood plasma [10]. It was shown that the loss-offunction mutations or inhibition of $11 \beta-H S D 2$ results in overstimulation of the mineralocorticoid receptor by glucocorticoids and causes salt-sensitive hypertension

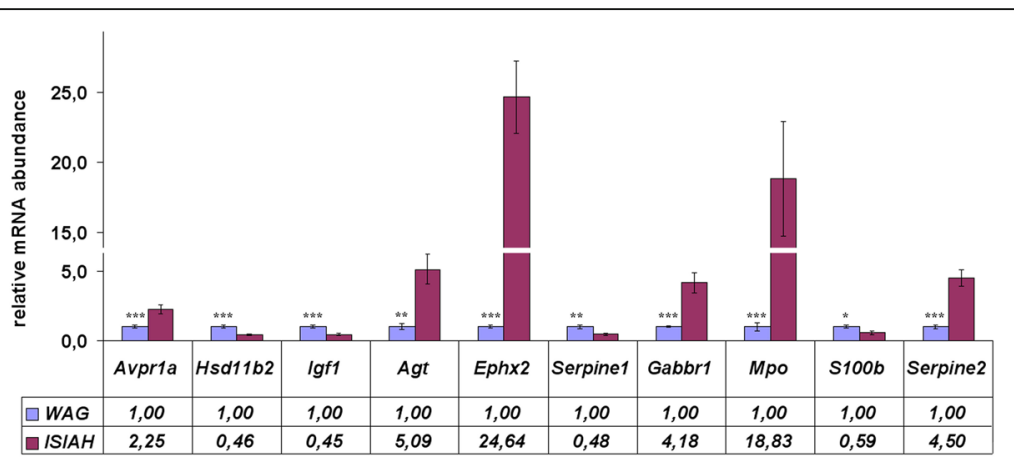

Fig. 4 The relative mRNA abundance measured by $q P C R$. The significance of inter-strain difference is indicated by ${ }^{*} p<0.05$, ${ }^{* *} p<0.01,{ }^{* * *} p<0.001$ 
[22]. Taking into account the decreased level of $H s d 11 b 2$ transcription and its protein activity in adrenal glands and other tissues of ISIAH rats, which resulted in decrease of 11-dehydrocorticosterone/corticosterone ratio in peripheral blood plasma, we may suggest the importance of this mechanism in stress-sensitive hypertension development, too.

The decreased transcription of Igf1 in ISIAH adrenals is in a good agreement with the observation that IGF1 expression may be significantly decreased in the presence of hypertension [23]. An increase in the IGF1 production was reported in rats undergoing the compensatory growth of the adrenal gland following the unilateral adrenalectomy [24]. As the weight of the adrenal glands is significantly higher in ISIAH rats as compared to WAG rats [25], we suggest that the decreased transcription of IgfI in ISIAH adrenals may be adaptive.

The data of the current study revealed also many other DEGs associated with hypertension and metabolic diseases, the main feature of which is insulin resistance. Adrenocortical dysregulation is considered as a major player in insulin resistance and onset of obesity [26]. It is believed that insulin resistance is directly correlated with the severity of hypertension [27] and may account for the etiology of essential hypertension in as many as half of the patients with the disease [28]. In the current study, three DEGs associated with both hypertension and insulin resistance (Agt, angiotensinogen; Ephx2, epoxide hydrolase 2; and Serpine1, serpin peptidase inhibitor, clade E (nexin, plasminogen activator inhibitor type 1 ), member 1) were put on the list of the top 10 DEGs making the most significant contribution to the interstrain differences (Table 4).

Angiotensinogen is the substrate of renin and the precursor of the angiotensin peptides having the powerful vasoconstrictive properties. The activation of reninangiotensin system (RAS) is considered not only as a main hypertensive system, but also as a key factor triggering reactive oxygen species production, oxidative stress, endothelial dysfunction and hypertension development [29]. The elevated transcription of the Agt gene in ISIAH adrenal glands points out the involvement of the adrenal tissue RAS in the development of stresssensitive hypertension. However, our data differ from those previously reported for spontaneously hypertensive rats (SHR). It was shown that adrenal angiotensinogen mRNAs were lower in SHR than in control WKY rats at 14 weeks of age [30]. This discrepancy is probably one of the features distinguishing the mechanism of hypertension development in ISIAH rats from that in SHRs.

Ephx2 encodes the soluble epoxide hydrolase (sEH) that metabolizes the epoxyeicosatrienoic acids, which produce vasorelaxation and exert anti-inflammatory and pro-fibrinolytic effects [31]. sEH was linked to hypertension in the studies on different animal models of the disease: spontaneous [32], angiotensin II-induced [33], and programmed hypertension [34]. Soluble epoxide hydrolase deficiency improves glucose homeostasis in a model of insulin resistance [35]. Taking into account the above information, we may suggest that Ephx2 activation may contribute to disease development in ISIAH rats.

The plasminogen activator inhibitor 1 (PAI1 or SERPINE1), known as coagulation marker, has been found to correlate with all components of the insulin resistance syndrome, and can be considered as a true component of the metabolic syndrome [36]. Increased plasma PAI1 may be involved in the occurrence of micro-vascular complications and increased risk of atherosclerosis [37]. The inhibition of PAI1 results in reduction of cell adhesion and cellular proliferation, particularly in reduction of angiogenesis [38]. So, decreased transcription of the Serpine1 in ISIAH adrenals may work against the excessive development of angiogenesis and micro-vascular complications in stress-sensitive hypertension.

As long as the PLS regression method is commonly used for biomarker selection in metabolomic [39] and gene expression [40] studies, the other DEGs listed in the Table 4 (Gabbrl, gamma-aminobutyric acid B receptor 1; Mpo, myeloperoxidase; S100b, S100 calcium binding protein B; and Serpine2, serpin peptidase inhibitor, clade E, member 2) may also be indicated as deserving a high priority in future investigations of molecular mechanisms of the stress-sensitive hypertension. Their possible contribution to the disease development in ISIAH rats is discussed below.

Metabotropic GABAB receptors (GABABRs) abundantly expressed at inhibitory and excitatory synapses are mostly studied in the brain, where they play an important role in modulating synaptic transmission by their presynaptic inhibitory effects on calcium channels and postsynaptic activating effects on potassium channels [41, 42]. It was also shown that activation of GABABRs protects neurons from apoptosis via IGF1 receptor transactivation [43]. However, gammaaminobutyric acid (GABA) is produced not only in the brain, but also in endocrine cells including rat adrenal medullary chromaffin cells. Since there are no GABAergic nerve fibers in the adrenal medulla, GABA may function as a para/autocrine factor [44]. The functional role of the elevated transcription of Gabbr1 in adrenal glands is not known and has to be studied, as it might be essential for stress-sensitive hypertension development in ISIAH rats.

Myeloperoxidase (MPO) delays neutrophil apoptosis and prolongs inflammation [45]. The activation of MPO may contribute to the development of obesity and obesity-associated insulin resistance [46]. So, it may be 
expected that the elevated Mpo transcription found in ISIAH adrenals in the current study may contribute to insulin resistance and inflammation in ISIAH rats, too.

$S 100 b$ expression is studied mostly in the central nervous system, where the role of S100 beta is related to the development and maintenance of neuronal function [47]. S100 beta may influence the cell survival in a concentration-dependent manner [48]. Recently, it was reported that the decreased expression of S100 beta may be associated with the neuroprotective mechanism against acute stress [49]. So, the role of the S100b decreased transcription in adrenal glands of ISIAH rats may be associated with the sympathetic nervous system regulation of the stress-sensitivity in ISIAH rats.

Serpine 2 encodes serine (or cysteine) proteinase inhibitor, clade E, member 2 (or protease nexin1, PN-1) which is associated with the negative regulation of blood coagulation [50, 51].

As it is seen from the above discussion, the top 10 DEGs making the most significant contribution to the inter-strain differences (Table 4) possess different functional properties and may contribute to many physiological mechanisms possibly related to hypertension development in ISIAH rats. Four of these DEGs (Agt, Avpr1a, Ephx2, and Hsd11b2) were related to GO term group 'regulation of $\mathrm{BP}$ '. Among the other members of this group there was the transcription factor Pparg.

The pathway enrichment analysis in KEGG database showed that the PPAR (peroxisome proliferatoractivated receptor) signaling pathway was among the most significantly enriched in the current study. The DEGs related to this pathway were mostly upregulated in ISIAH adrenal glands (Additional file 7). Among the upregulated DEGs there were 6 genes associated with hypertension, including the Adipoq and Lpl genes encoding adiponectin and lipoprotein lipase, which are recognized as an indicators for PPAR-gamma activation [52-54]. In the current study two genes (Ppard and Pparg) encoding the members of the PPAR subfamily of nuclear receptors were upregulated.

The physiological role of PPARs is related to lipid metabolism and energy homeostasis [53]. PPAR-gamma has been implicated in the pathology of numerous diseases including insulin resistance, diabetes, atherosclerosis and hypertension [55, 56]. PPAR-gamma activation attenuates insulin resistance and inflammation $[57,58]$. PPARdelta activation ameliorates obesity and insulin resistance [59], and has been considered as a potential therapeutic target in treatment of lipid-related disorders, including dyslipidemia and diabetes [60, 61].

Earlier it was shown that the hypertension development in ISIAH rats is accompanied by dislipidemia, increased glucose content, increased body weight, and enhanced DNA-binding activity of several transcription factors including PPARs in liver. These data suggested the development of metabolic syndrome in ISIAH rats [62]. Probably, the elevated transcription of Pparg and Ppard in the adrenal gland of ISIAH rats plays adaptive role and is directed to the attenuation of the processes leading to the metabolic syndrome development.

Both GO and KEGG analyses indicated the high impact of the immune system processes on the formation of the interstrain differences in ISIAH and WAG rats (Fig. 1 and Additional file 7). Multiple DEGs associated with GO term 'immune system process' are annotated in RGD as associated with hypertension. The important role of inflammation and immunity in development of the stress-sensitive hypertension was already highlighted in our previous comparative studies of genome-wide transcriptome analyses of hypothalamus and renal cortex from ISIAH and WAG rats [63, 64]. A growing body of research supporting a role of inflammation and immunity in hypertension was recently summarized in multiple reviews [65-72]. Many of the authors reviewing the problem consider that cells of both the innate and adaptive immune system contribute to end-organ damage and dysfunction in hypertension, and the molecular determinants of the immune cells activation may be a putative therapeutic targets to reduce end-organ damage and prevent pathological consequences of hypertension $[68,69,73]$. The results of our study are in a good agreement with these opinions and may be useful to define the common molecular determinants, which may be recognized as potential targets for therapy and prevention of hypertensive disease.

\section{Conclusion}

Recently, the molecular studies of the pathogenesis of genetic hypertension strongly highlighted the complex nature of the disease. The current study of the comparative transcriptional profiling of the adrenal glands in ISIAH rats with the stress-sensitive arterial hypertension and control WAG rats resulted in detection of multiple DEGs related to different endocrine, inflammatory, neural, and metabolic processes and pathways. The discussion of the results helped to prioritize the following genes.

Two transcription factor genes (Nr4a3 and Ppard) were found to be common and upregulated both in adrenal of ISIAH rats and in the adrenal medulla from the Sprague-Dawley rats after acute immobilization stress. We suggest that the upregulation of these genes may be related to the predominant activation of the sympathetic-adrenal medullary axis in ISIAH rats; however, their real contribution to the hypertensive phenotype remains to be demonstrated.

The use of the PLS-DA helped to reveal a number of DEGs making the most significant contribution to the 
inter-strain differences. The discussion of ten of them known as associated with hypertension demonstrated that four of these genes (Avpr1a, Hsd11b2, Agt, Ephx2) may provoke the hypertension development, and $M p o$ may contribute to insulin resistance and inflammation in ISIAH rats. These DEGs may be considered as the most promising candidates for further studies of the mechanisms underlying the stress-sensitive hypertension development.

It was not possible to discuss the functional roles for all the DEGs found in the current study. The differential expression of the genes not necessary must be related to hypertensive phenotype. So, the attention was mostly paid to the discussion of the DEGs already known as associated with hypertension, which could be considered as the most potentially interesting candidates for further studies of the mechanisms underlying the stresssensitive hypertension development. However, the list of genes associated with hypertension is permanently expanding. Thus, we can't exclude that the other genes found to be differentially expressed in ISIAH and WAG adrenal glands may also influence the development of hypertensive phenotype.

The results of the current study may be useful to identify the common molecular determinants in different animal models of arterial hypertension and to define the potential targets for therapy and prevention of hypertensive disease.

\section{Methods}

\section{Animals}

The study was performed using the hypertensive ISIAH/ Icgn and normotensive WAG/GSto-Icgn rat strains. The rats from both strains were bred in the Center for Genetic Resources of Laboratory Animals at the Institute of Cytology and Genetics, SB RAS, Novosibirsk, Russia (Identification numbers in the list of National Animal Facilities of Russia RFMEFI61914X0005 and RFMEFI62114X0010).

The ISIAH rat strain (Inherited Stress-Induced Arterial Hypertension) is a rat model with the genetically determined exaggerated sensitivity to stressful stimuli [9]. The ISIAH rats were selected for a strong elevation of the systolic arterial blood pressure (SABP) in response to a brief emotional stress. To cause the emotional stress the animal was kept for $30 \mathrm{~min}$ in a small cylindrical wire mesh cage $[7,8]$. This procedure leads to $20-$ $25 \mathrm{mmHg}$ elevation of SABP in ISIAH rats and doesn't cause the significant changes of SABP in WAG rats used as a normotensive control. Both ISIAH and WAG rat strains derived from outbred Wistar rats. The process of ISIAH rat strain selection for the dramatic increase of SABP during mild emotional stress was accompanied by the elevation of the SABP at rest condition, which is about $175.0 \pm 3.5 \mathrm{mmHg}$ in males and $165.0 \pm 3.0 \mathrm{mmHg}$ in females from the current population. The high degree of genetic homogeneity of the ISIAH strain was confirmed by the DNA fingerprinting approach [74].

All rats were kept under the standard environmental conditions with ad libitum access to food and water. Animals were individually caged a week before the SABP measurement, which was done indirectly by the tail-cuff method with the use of short-term ether anesthesia. The preliminary work showed that the blood pressure measured in the ether anesthetized rats is close to the measures made in the unanesthetized rats after many days of adaptation to the procedure of indirect tail-cuff method as well as to the blood pressure levels measured in the home-cage drectly trough indwelling arterial catheter.

The RNA-Seq experiments were conducted on ISIAH and WAG males aged 3-month old. Each experimental group consisted of three rats. Their SABP was $171.7 \pm$ $1.2 \mathrm{mmHg}$ and $116.3 \pm 1.9 \mathrm{mmHg}$ in ISIAH and WAG males, correspondingly. Six days after SABP measurement, rats were decapitated, and their left adrenal glands were immediately removed and stored in RNA Later (Qiagen, Chatsworth, CA) at $-70{ }^{\circ} \mathrm{C}$. The relative amount of target mRNA was measured by semiquantitative real-time PCR (qPCR) in the left adrenal glands from 3-month old ISIAH and WAG male rats. Each group consisted of seven rats. Their SABP was measured as described above. It was $174.3 \pm 1.3 \mathrm{mmHg}$ in ISIAH and $122.1 \pm 1.8 \mathrm{mmHg}$ in WAG rats. The rats were also decapitated 6 days after measurement of SABP, and their left adrenal glands were rapidly removed, frozen and stored at $-70{ }^{\circ} \mathrm{C}$ until use.

The animal experiments protocols received approval of the Institute's Animal Care and Use Committee.

\section{RNA-Seq analysis}

The technological part of the RNA-seq analysis was performed in JSC Genoanalytica (Moscow, Russia). The mRNA from the samples of agrenal glands was extracted using Dynabeads mRNA Purification Kit (Ambion, USA). NEBNext mRNA Library Prep Reagent Set for Illumina (NEB, USA) was used to construct the cDNA libraries following the manufacturer's protocol. The single-end sequencing of the cDNA libraries was carried out on Illumina HiSeq1500 Sequencing System (Illumina Sequencing, San Diego, USA) with read length of 50 bases. All samples were run as biological replicates. The sequencing data after adapter trimming and low-quality sequence removal were mapped to the RGSC Rnor_5.0\rn5 reference genome with the use of Tophat2 aligner [75]. CollectRnaSeqMetrics from the Picard tools suit (http://broadinstitute.github.io/picard/) was used to collect the quality metrics of the mapped data (Additional file 9). The Cufflinks program was employed to count gene expression levels in FPKM (fragments per kilobase of transcript per million mapped reads). Gene 
annotation was based on NCBI Gene/RefSeq database. A gene was defined as being expressed if it has successfully passed the Cufflinks statistical testing and was assigned to test status 'OK'. Cuffdiff was used to identify the genes with differential expression under a false discovery rate (FDR) threshold of 0.05 [76]. The RNA-Seq data were deposited in the NCBI SRA database under the Accession number: PRJNA299102.

\section{Functional annotation}

The DAVID (The Database for Annotation, Visualization and Integrated Discovery) tool (http://david.abcc.ncifcrf.gov/) was employed for functional annotation of DEGs $[77,78]$. The Rattus norvegicus genome was utilized as the background list for the over-representation analysis. The Gene Ontology option was used to identify the significantly $(p<0.05)$ enriched biological processes. The Kyoto Encyclopedia of Genes and Genomes (KEGG, http://www.genome.jp/kegg/) Pathway Database was used to identify the significantly $(p<0.05)$ enriched metabolic pathways. The annotation of DEGs in Rat Genome Database (RGD, http://rgd.mcw.edu/) helped to reveal the genes associated with hypertension and metabolic diseases. The DEGs were annotated in GenBank (http://www.ncbi.nlm.nih.gov/gene/), an atlas of combinatorial transcriptional regulation in mouse and man [79], and Panther classification system (http:// www.pantherdb.org/) [80] to reveal those encoding the transcription factors.

\section{qPCR}

The extraction of the total RNA was carried out with the use of the TRI reagent RNA isolation protocol (Molecular research center, USA), and the residual genomic DNA was removed from the total RNA samples by DNase I (Promega, USA) treatment, following the manufacturer's instructions.

The reaction mixture for reverse transcription contained reverse transcription buffer (Vektor-Best, RF), $0.25 \mathrm{nmol}$ of random nonanucleotide primers (Biosan, $\mathrm{RF}), 0.4 \mathrm{mM}$ dNTPs, $3 \mu \mathrm{g}$ of RNA, and 40 units of MoMLV (Vektor-Best, RF) in the total volume of $50 \mu \mathrm{l}$. The protocol for cDNA synthesis was as follows: $1 \mathrm{~h}$ at $37{ }^{\circ} \mathrm{C}, 30 \mathrm{~min}$ at $42{ }^{\circ} \mathrm{C}$, and $10 \mathrm{~min}$ at $50{ }^{\circ} \mathrm{C}$. The enzyme was inactivated by heating the reaction mixture during 5 min at $75^{\circ} \mathrm{C}$.

qPCR was carried out in a final volume of $20 \mu \mathrm{l}$ containing a master mix with SYBR Green, $0.15 \mathrm{mM}$ of each forward and reverse primers, the cDNA template, and 1 unit of HotStart Taq polymerase (Vektor-Best, RF). The Ppia (peptidylprolyl isomerase A) was used as a reference gene. Primer sequences and their characteristics are represented in Additional file 10.
The iCycler iQ4 Real-Time PCR Detection System (Bio-Rad Laboratories, USA) was used to run qPCR. The reaction was started at $94{ }^{\circ} \mathrm{C}$ for $1 \mathrm{~min}$ and followed by 40 cycles of $15 \mathrm{~s}$ at $94{ }^{\circ} \mathrm{C}, 20 \mathrm{~s}$ at primer's annealing temperatures listed in Additional file 10, $20 \mathrm{~s}$ at $72{ }^{\circ} \mathrm{C}$, and fluorescence signal acquisition (10 s). The melting curve was generated in the range of $65{ }^{\circ} \mathrm{C}$ to $94{ }^{\circ} \mathrm{C}$. Relative transcript levels were determined with the use of standard-curve quantitation method [81]. The aliquots from each of the synthesized cDNA samples were pooled and used as the standard cDNA. The qPCR was run using the same cDNA samples with primers for the target gene and for the reference gene, which were loaded onto the plate as four replicates per cDNA sample, and the standard cDNA dilutions $(1: 1,1: 4,1: 16$, and $1: 64$ ) with the primers for the target gene (two replicates), and for the reference gene (two replicates) loaded onto the same plate. iCycler iQ4 Real-Time PCR Detection System software was used to build the calibration curves for calculation of the relative amount of cDNAs.

The value for the target gene was normalized against the value obtained for the reference gene. The relative mRNA abundance was calculated as a ratio of the normalized mRNA level calculated for the experimental ISIAH samples to the normalized mRNA level obtained for the samples from control WAG rats, which was set a value of 1 .

\section{Statistical methods}

Statistical significance for $\mathrm{qPCR}$ data was calculated by Student's $t$-test. A $p$ value $<0.05$ was considered significant. Data were expressed as means and standard errors of means $(\mathrm{M} \pm \mathrm{SEM})$.

The data (FPKM values) obtained from RNA-Seq were $\log$ transformed, centered, and normalized. The principal coordinates analysis based on Euclidean metric distances was employed to scale the data sets, and PLS-DA was used to construct the PLS-DA Axes maximizing the distances between ISIAH and WAG rats. Then, the Pearson correlation was explored to determine a set of variables (i.e. expressed genes) that maximize the covariance between gene expression in ISIAH and WAG rats and fixed dummy matrix representing group membership [82] for rats from different strains. These procedures helped to define the genes showing the most deviation along the axis representing the correlation between gene expression and PLS-DA Axis 1, which were assumed as genes contributing the most to inter-strain variations. The Pearson correlation between mean values (represented as $\log$ (fold_change)ISIAH/WAG) obtained by RNA-Seq and qPCR for 10 genes (Agt, Avpr1a, Ephx2, Gabbr1, Hsd11b2, Igf1, Mpo, S100b, Serpine1, Serpine2) was used to count the correlation coefficient between the results derived from these methods. 


\section{Additional files}

Additional file 1: Genes differentially expressed in adrenal glands of 3 month old hypertensive ISIAH and normotensive control WAG rats. (XLS $214 \mathrm{~kb}$ )

Additional file 2: Heatmap of the differentially expressed genes in the adrenal glands of the ISIAH and WAG rats. (PDF $88 \mathrm{~kb}$ )

Additional file 3: The genes with the detected expression in adrenal gland of only one rat strain. (XLS $17 \mathrm{~kb}$ )

Additional file 4: Functional annotation of differentially expressed genes (DEGs) found in 3-month old ISIAH and WAG adrenal glands. (XLS $148 \mathrm{~kb}$ )

Additional file 5: Gene Ontology (GO) terms specifying the main $\mathrm{GO}$ terms. (JPG $500 \mathrm{~kb}$ )

Additional file 6: Differentially expressed genes (DEGs) in GO term groups, which might be important for the development of the stresssensitive hypertension in ISIAH rats. (XLS 303 kb)

Additional file 7: KEGG metabolic pathways enriched with genes differentially expressed in 3-month old ISIAH and WAG adrenal glands. (XLS $52 \mathrm{~kb}$ )

Additional file 8: The comparison of the relative mRNA abundance between the RNA-Seq and qPCR measurements. (JPG $261 \mathrm{~kb}$ )

Additional file 9: The summary statistics for the sequenced libraries. (XLS $14 \mathrm{~kb}$ )

Additional file 10: Primers used in GPCR. (DOC $41 \mathrm{~kb}$ )

\section{Abbreviations}

BP: Blood pressure; DAVID: Database for annotation, visualization and integrated discovery; DEG: Differentially expressed genes; FDR: False discovery rate; FPKM: Fragments per kilobase of transcript per million mapped reads; GO: Gene ontology; HPA: Hypothalamic-pituitary-adrenal; ISIAH: Inherited stress-induced arterial hypertension; KEGG: Kyoto encyclopedia of genes and genomes pathway database; PLS-DA: Partial-least squares discriminant analysis; qPCR: Quantitative real time polymerase chain reaction; RAS: Renin-angiotensin system; RGD: Rat genome database; RNASeq: RNA sequencing; RT: Reverse transcription; SAS: Sympathoadrenal system; sEH: Soluble epoxide hydrolase; WAG: Wistar Albino Glaxo

\section{Acknowledgements}

The authors are grateful to JSC Genoanalytica (Moscow, Russia) for conducting the technological part of the RNA-Seq experiment and the primary statistical analysis. This work has been supported by the Russian Science Foundation, grant No. 14-15-00118. The Siberian Branch of the Russian Academy of Sciences (SB RAS) Siberian Supercomputer Center is gratefully acknowledged for providing supercomputer facilities.

\section{Declarations}

This article has been published as part of BMC Genomics Vol 17 Suppl 14 2016: Selected articles from BGRSISB-2016: genomics. The full contents of the supplement are available online at http://

bmcgenomics.biomedcentral.com/articles/supplements/volume-17supplement-14.

\section{Funding}

Publication of this article has been funded by the Russian Science Foundation (grant 14-15-00118).

\section{Availability of data and material}

The data sets supporting the results of this article are included within the article and its additional files. The RNA-Seq data were deposited in the NCBI Short Read Archive database with Accession number: PRJNA299102.

\section{Authors' contributions}

LF and LK performed quantitative real time PCR, participated in interpretation of data, and helped to draft the manuscript; NE has made substantial contribution to bioinformatics analysis; YuA performed the functional analysis of DEGs; VE has made substantial contributions to conception and use of multivariate statistical analysis; AM has made substantial contributions to conception and design of the study and participated in interpretation of data; OR participated in interpretation of data and drafted the manuscript. All authors read and approved the final manuscript.

\section{Competing interests}

The authors declare that they have no competing interests. The authors alone are responsible for the content and writing of the paper.

\section{Consent for publication}

Not applicable.

\section{Ethics approval}

All animal experiments were approved by the Institute's Animal Care and Use Committee.

\section{Author details}

${ }^{1}$ Institute of Cytology and Genetics, Siberian Branch of Russian Academy of Sciences, Novosibirsk, Russian Federation. ${ }^{2}$ Novosibirsk State University, Novosibirsk, Russian Federation.

Published: 28 December 2016

\section{References}

1. De Champlain J, Van Ameringen MR. Regulation of blood pressure by sympathetic nerve fibers and adrenal medulla in normotensive and hypertensive rats. Circ Res. 1972;31:617-28.

2. Lewicka $S$, Nowicki M, Vecsei P. Effect of sodium restriction on urinary excretion of cortisol and its metabolites in humans. Steroids. 1998;63:401-5.

3. Friese RS, Mahboubi P, Mahapatra NR, Mahata SK, Schork NJ, SchmidSchonbein GW, O'Connor DT. Common genetic mechanisms of blood pressure elevation in two independent rodent models of human essential hypertension. Am J Hypertens. 2005;18:633-52.

4. Romero DG, Plonczynski MW, Welsh BL, Gomez-Sanchez CE, Zhou MY, Gomez-Sanchez EP. Gene expression profile in rat adrenal zona glomerulosa cells stimulated with aldosterone secretagogues. Physiol Genomics. 2007;32: 117-27.

5. Liu X, Serova L, Kvetnansky R, Sabban EL. Identifying the stress transcriptome in the adrenal medulla following acute and repeated immobilization. Ann N Y Acad Sci. 2008;1148:1-28.

6. Friese RS, Ye C, Nievergelt CM, Schork AJ, Mahapatra NR, Rao F, Napolitan PS, Waalen J, Ehret GB, Munroe PB, Schmid-Schonbein GW, Eskin E, O'Connor DT. Integrated computational and experimental analysis of the neuroendocrine transcriptome in genetic hypertension identifies novel control points for the cardiometabolic syndrome. Circ Cardiovasc Genet. 2012;5:430-40

7. Markel AL. Development of a new strain of rats with inherited stressinduced arterial hypertension. In: Sassard J, editor. Genetic hypertension, vol. 218. Paris: Colloque INSERM; 1992. p. 405-7.

8. Markel AL, Maslova LN, Shishkina GT, Bulygina W, Machanova NA, Jacobson GS. Developmental influences on blood pressure regulation in ISIAH rats. In: McCarty R, Blizard DA, Chevalier RL, editors. Development of the hypertensive phenotype: basic and clinical studies, vol. 19. AmsterdamLausanne- NewYork- Oxford- Shannon- Singapore- Tokyo: Elsevier; 1999. p. 493-526

9. Markel AL, Redina OE, Gilinsky MA, Dymshits GM, Kalashnikova EV Khvorostova YV, Fedoseeva LA, Jacobson GS. Neuroendocrine profiling in inherited stress-induced arterial hypertension rat strain with stress-sensitive arterial hypertension. J Endocrinol. 2007;195:439-50.

10. Antonov YV, Alexandrovich Y, Redina OE, Gilinsky MA, Markel AL. Stress and hypertensive disease: adrenals as a link. Experimental study on hypertensive ISIAH rat strain. Clin Exp Hypertens. 2016;38:415-23.

11. Yu Y, Fuscoe JC, Zhao C, Guo C, Jia M, Qing T, Bannon DI, Lancashire L, Bao W, Du T, Luo H, Su Z, Jones WD, Moland CL, Branham WS, Qian F, Ning B, Li Y, Hong H, Guo L, Mei N, Shi T, Wang KY, Wolfinger RD, Nikolsky Y, Walker SJ, Duerksen-Hughes P, Mason CE, Tong W, Thierry-Mieg J, Thierry-Mieg D, Shi L, Wang C. A rat RNA-Seq transcriptomic BodyMap across 11 organs and 4 developmental stages. Nat Commun. 2014;5:3230.

12. Miller DB, O'Callaghan JP. Neuroendocrine aspects of the response to stress. Metabolism. 2002;51:5-10. 
13. Bierhaus A, Wolf J, Andrassy M, Rohleder N, Humpert PM, Petrov D, Ferstl R, von Eynatten M, Wendt T, Rudofsky G, Joswig M, Morcos M, Schwaninger M, McEwen B, Kirschbaum C, Nawroth PP. A mechanism converting psychosocial stress into mononuclear cell activation. Proc Natl Acad Sci U S A. 2003;100:1920-5.

14. Pearen MA, Myers SA, Raichur S, Ryall JG, Lynch GS, Muscat GE. The orphan nuclear receptor, NOR-1, a target of beta-adrenergic signaling, regulates gene expression that controls oxidative metabolism in skeletal muscle. Endocrinology. 2008;149:2853-65.

15. Guerineau NC, Desarmenien MG. Developmental and stress-induced remodeling of cell-cell communication in the adrenal medullary tissue. Cell Mol Neurobiol. 2010;30:1425-31.

16. Sala F, Nistri A, Criado M. Nicotinic acetylcholine receptors of adrenal chromaffin cells. Acta Physiol (Oxf). 2008;192:203-12.

17. Matsumura K, Tsuchihashi T, Abe I. Central human cocaine- and amphetamine-regulated transcript peptide 55-102 increases arterial pressure in conscious rabbits. Hypertension. 2001;38:1096-100.

18. Koshimizu TA, Nasa Y, Tanoue A, Oikawa R, Kawahara Y, Kiyono Y, Adachi T, Tanaka T, Kuwaki T, Mori T, Takeo S, Okamura H, Tsujimoto G. V1a vasopressin receptors maintain normal blood pressure by regulating circulating blood volume and baroreflex sensitivity. Proc Natl Acad Sci U S A. 2006;103:7807-12.

19. Guillon G, Grazzini E, Andrez M, Breton C, Trueba M, Serradeil-LeGal C, Boccara G, Derick S, Chouinard L, Gallo-Payet N. Vasopressin : a potent autocrine/paracrine regulator of mammal adrenal functions. Endocr Res. 1998;24:703-10

20. Russell JA. Vasopressin in vasodilatory and septic shock. Curr Opin Crit Care. 2007:13:383-91.

21. Antonov $\mathrm{YV}$. The secretory activity of adrenal glands in the stress-sensitive arterial hypertension: the experimental study on ISIAH rat strain, PhD Thesis. 2013. http://icg.nsc.ru/isiah/en/category/publications/

22. Ferrari $P$. The role of 11 beta-hydroxysteroid dehydrogenase type 2 in human hypertension. Biochim Biophys Acta. 2010;1802:1178-87.

23. Fernandez-Sola J, Borrisser-Pairo F, Antunez E, Tobias E. Myostatin and insulin-like growth factor-1 in hypertensive heart disease: a prospective study in human heart donors. J Hypertens. 2015;33:851-8.

24. Jackson S, Hodgkinson S, Estivariz FE, Lowry PJ. IGF1 and 2 in two models of adrenal growth. J Steroid Biochem Mol Biol. 1991:40:399-404.

25. Amstislavsky S, Welker P, Fruhauf JH, Maslova L, Ivanova L, Jensen B, Markel $\mathrm{AL}$, Bachmann S. Renal and endocrine changes in rats with inherited stressinduced arterial hypertension (ISIAH). Histochem Cell Biol. 2006;125:651-9.

26. Roberge C, Carpentier AC, Langlois MF, Baillargeon JP, Ardilouze JL, Maheux P, Gallo-Payet N. Adrenocortical dysregulation as a major player in insulin resistance and onset of obesity. Am J Physiol Endocrinol Metab. 2007;293:E1465-78.

27. Ferrannini E, Buzzigoli G, Bonadonna R, Giorico MA, Oleggini M, Graziadei L, Pedrinelli R, Brandi L, Bevilacqua S. Insulin resistance in essential hypertension. N Engl J Med. 1987;317:350-7.

28. Reaven GM. Insulin resistance/compensatory hyperinsulinemia, essential hypertension, and cardiovascular disease. J Clin Endocrinol Metab. 2003;88: 2399-403.

29. Manrique C, Lastra G, Gardner M, Sowers JR. The renin angiotensin aldosterone system in hypertension: roles of insulin resistance and oxidative stress. Med Clin North Am. 2009;93:569-82.

30. Tamura K, Umemura S, Nyui N, Yamakawa T, Yamaguchi S, Ishigami T, Tanaka S, Tanimoto K, Takagi N, Sekihara H, Murakami K, Ishii M. Tissuespecific regulation of angiotensinogen gene expression in spontaneously hypertensive rats. Hypertension. 1996;27:1216-23.

31. Spector AA, Fang X, Snyder GD, Weintraub NL. Epoxyeicosatrienoic acids (EETs): metabolism and biochemical function. Prog Lipid Res. 2004:43:55-90.

32. Sellers KW, Sun C, Diez-Freire C, Waki H, Morisseau C, Falck JR, Hammock BD, Paton JF, Raizada MK. Novel mechanism of brain soluble epoxide hydrolase-mediated blood pressure regulation in the spontaneously hypertensive rat. FASEB J. 2005;19:626-8

33. Imig JD, Zhao X, Capdevila JH, Morisseau C, Hammock BD. Soluble epoxide hydrolase inhibition lowers arterial blood pressure in angiotensin II hypertension. Hypertension. 2002;39:690-4.

34. Tain YL, Huang LT, Chan JY, Lee CT. Transcriptome analysis in rat kidneys: importance of genes involved in programmed hypertension. Int J Mol Sci. 2015;16:4744-58

35. Luria A, Bettaieb A, Xi Y, Shieh GJ, Liu HC, Inoue H, Tsai HJ, Imig JD, Haj FG, Hammock BD. Soluble epoxide hydrolase deficiency alters pancreatic islet size and improves glucose homeostasis in a model of insulin resistance. Proc Natl Acad Sci U S A. 2011;108:9038-43.

36. Mertens I, Verrijken A, Michiels JJ, Van der Planken M, Ruige JB, Van Gaal LF. Among inflammation and coagulation markers, PAl-1 is a true component of the metabolic syndrome. Int J Obes (Lond). 2006;30:1308-14.

37. Adly AA, Elbarbary NS, Ismail EA, Hassan SR. Plasminogen activator inhibitor1 (PAI-1) in children and adolescents with type 1 diabetes mellitus: relation to diabetic micro-vascular complications and carotid intima media thickness. J Diabetes Complications. 2014;28:340-7.

38. Gomes-Giacoia E, Miyake M, Goodison S, Rosser CJ. Targeting plasminogen activator inhibitor-1 inhibits angiogenesis and tumor growth in a human cancer xenograft model. Mol Cancer Ther. 2013;12:2697-708.

39. Szymanska E, Saccenti E, Smilde AK, Westerhuis JA. Double-check: validation of diagnostic statistics for PLS-DA models in metabolomics studies. Metabolomics. 2012:8 Suppl 1:3-16.

40. Perez-Enciso M, Tenenhaus M. Prediction of clinical outcome with microarray data: a partial least squares discriminant analysis (PLS-DA) approach. Hum Genet. 2003;112:581-92.

41. Bettler B, Kaupmann K, Mosbacher J, Gassmann M. Molecular structure and physiological functions of GABA(B) receptors. Physiol Rev. 2004;84:835-67.

42. Chalifoux JR, Carter AG. GABAB receptor modulation of synaptic function. Curr Opin Neurobiol. 2011;21:339-44.

43. Tu H, Xu C, Zhang W, Liu Q, Rondard P, Pin JP, Liu J. GABAB receptor activation protects neurons from apoptosis via IGF-1 receptor transactivation. J Neurosci. 2010;30:749-59.

44. Harada K, Matsuoka H, Fujihara H, Ueta Y, Yanagawa Y, Inoue M. GABA Signaling and Neuroactive Steroids in Adrenal Medullary Chromaffin Cells. Front Cell Neurosci. 2016;10:100.

45. El Kebir D, Jozsef L, Pan W, Filep JG. Myeloperoxidase delays neutrophil apoptosis through CD11b/CD18 integrins and prolongs inflammation. Circ Res. 2008;103:352-9

46. Wang Q, Xie Z, Zhang W, Zhou J, Wu Y, Zhang M, Zhu H, Zou MH. Myeloperoxidase deletion prevents high-fat diet-induced obesity and insulin resistance. Diabetes. 2014;63:4172-85.

47. Winningham-Major F, Staecker JL, Barger SW, Coats S, Van Eldik LJ. Neurite extension and neuronal survival activities of recombinant S100 beta proteins that differ in the content and position of cysteine residues. J Cell Biol. 1989:109:3063-71.

48. Huttunen HJ, Kuja-Panula J, Sorci G, Agneletti AL, Donato R, Rauvala H. Coregulation of neurite outgrowth and cell survival by amphoterin and S100 proteins through receptor for advanced glycation end products (RAGE) activation. J Biol Chem. 2000;275:40096-105.

49. Ragy M, Ali F, Ramzy MM. Effect of Hemin on Brain Alterations and Neuroglobin Expression in Water Immersion Restraint Stressed Rats. Scientifica (Cairo). 2016:2016:7825396.

50. Bouton MC, Venisse L, Richard B, Pouzet C, Arocas V, Jandrot-Perrus M. Protease nexin-1 interacts with thrombomodulin and modulates its anticoagulant effect. Circ Res. 2007;100:1174-81.

51. Boulaftali Y, Adam F, Venisse L, Ollivier V, Richard B, Taieb S, Monard D, Favier R, Alessi MC, Bryckaert M, Arocas V, Jandrot-Perrus M, Bouton MC. Anticoagulant and antithrombotic properties of platelet protease nexin-1. Blood. 2010;115:97-106.

52. Schoonjans K, Peinado-Onsurbe J, Lefebvre AM, Heyman RA, Briggs M, Deeb S, Staels B, Auwerx J. PPARalpha and PPARgamma activators direct a distinct tissue-specific transcriptional response via a PPRE in the lipoprotein lipase gene. EMBO J. 1996;15:5336-48.

53. Desvergne B, Wahli W. Peroxisome proliferator-activated receptors: nuclear control of metabolism. Endocr Rev. 1999;20:649-88.

54. Yang B, Brown KK, Chen L, Carrick KM, Clifton LG, McNulty JA, Winegar DA, Strum JC, Stimpson SA, Pahel GL. Serum adiponectin as a biomarker for in vivo PPARgamma activation and PPARgamma agonist-induced efficacy on insulin sensitization/lipid lowering in rats. BMC Pharmacol. 2004:4:23.

55. Tontonoz P, Nagy L, Alvarez JG, Thomazy VA, Evans RM. PPARgamma promotes monocyte/macrophage differentiation and uptake of oxidized LDL. Cell. 1998;93:241-52.

56. Barroso I, Gurnell M, Crowley VE, Agostini M, Schwabe JW, Soos MA, Maslen GL, Williams TD, Lewis H, Schafer AJ, Chatterjee VK, O'Rahilly S. Dominant negative mutations in human PPARgamma associated with severe insulin resistance, diabetes mellitus and hypertension. Nature. 1999;402:880-3.

57. Pfutzner A, Hohberg $C$, Lubben $G$, Pahler S, Pfutzner AH, Kann P, Forst $T$. Pioneer study: PPARgamma activation results in overall improvement of 
clinical and metabolic markers associated with insulin resistance independent of long-term glucose control. Horm Metab Res. 2005;37:510-5.

58. Foryst-Ludwig A, Hartge M, Clemenz M, Sprang C, Hess K, Marx N, Unger T, Kintscher U. PPARgamma activation attenuates T-lymphocyte-dependent inflammation of adipose tissue and development of insulin resistance in obese mice. Cardiovasc Diabetol. 2010;9:64.

59. Tanaka T, Yamamoto J, Iwasaki S, Asaba H, Hamura H, Ikeda Y, Watanabe M, Magoori K, loka RX, Tachibana K, Watanabe Y, Uchiyama Y, Sumi K, Iguchi H, Ito S, Doi T, Hamakubo T, Naito M, Auwerx J, Yanagisawa M, Kodama T, Sakai J. Activation of peroxisome proliferator-activated receptor delta induces fatty acid beta-oxidation in skeletal muscle and attenuates metabolic syndrome. Proc Natl Acad Sci U S A. 2003;100:15924-9.

60. Wang YX, Lee CH, Tiep S, Yu RT, Ham J, Kang H, Evans RM. Peroxisomeproliferator-activated receptor delta activates fat metabolism to prevent obesity. Cell. 2003;113:159-70.

61. Lee CH, Kang K, Mehl IR, Nofsinger R, Alaynick WA, Chong LW, Rosenfeld JM, Evans RM. Peroxisome proliferator-activated receptor delta promotes very low-density lipoprotein-derived fatty acid catabolism in the macrophage. Proc Natl Acad Sci U S A. 2006;103:2434-9.

62. Pivovarova EN, Dushkin MI, Perepechaeva ML, Kobzev VF, Trufakin VA, Markel' AL. [All signs of metabolic syndrome in the hypertensive ISIAH rats are associated with increased activity of transcription factors PPAR, LXR, PXR, and CAR in the liver]. [Article in Russian]. Biomed Khim. 2011;57:435-45.

63. Klimov LO, Ershov NI, Efimov VM, Markel AL, Redina OE. Genome-wide transcriptome analysis of hypothalamus in rats with inherited stress-induced arterial hypertension. BMC Genet. 2016;17 Suppl 1:13.

64. Fedoseeva LA, Ryazanova MA, Ershov NI, Markel AL, Redina OE. Comparative transcriptional profiling of renal cortex in rats with inherited stress-induced arterial hypertension and normotensive Wistar Albino Glaxo rats. BMC Genet. 2016;17 Suppl 1:12

65. Harrison DG, Guzik TJ, Lob HE, Madhur MS, Marvar PJ, Thabet SR, Vinh A, Weyand CM. Inflammation, immunity, and hypertension. Hypertension. 2011;57:132-40.

66. Mian MO, Paradis P, Schiffrin EL. Innate immunity in hypertension. Curr Hypertens Rep. 2014;16:413.

67. De Ciuceis C, Rossini C, La Boria E, Porteri E, Petroboni B, Gavazzi A, Sarkar A, Rosei EA, Rizzoni D. Immune mechanisms in hypertension. High Blood Press Cardiovasc Prev. 2014;21:227-34.

68. Virdis A, Dell'Agnello $U$, Taddei S. Impact of inflammation on vascular disease in hypertension. Maturitas. 2014;78:179-83.

69. Singh MV, Chapleau MW, Harwani SC, Abboud FM. The immune system and hypertension. Immunol Res. 2014;59:243-53.

70. Rodriguez-Iturbe B, Pons H, Quiroz Y, Johnson RJ. The immunological basis of hypertension. Am J Hypertens. 2014;27:1327-37.

71. De Miguel C, Rudemiller NP, Abais JM, Mattson DL. Inflammation and hypertension: new understandings and potential therapeutic targets. Curr Hypertens Rep. 2015;17:507.

72. Anders HJ, Baumann M, Tripepi G, Mallamaci F. Immunity in arterial hypertension: associations or causalities? Nephrol Dial Transplant. 2015;30:1959-64.

73. McMaster WG, Kirabo A, Madhur MS, Harrison DG. Inflammation, immunity, and hypertensive end-organ damage. Circ Res. 2015;116:1022-33.

74. Adarichev VA, Korokhov NP, Ostapchuk IV, Dymshits GM, Markel AL. Characterization of rat lines with normotensive and hypertensive status using genomic fingerprinting. Genetika. 1996;32:1669-72.

75. Kim D, Pertea G, Trapnell C, Pimentel H, Kelley R, Salzberg SL. TopHat2: accurate alignment of transcriptomes in the presence of insertions, deletions and gene fusions. Genome Biol. 2013;14:R36.

76. Trapnell C, Hendrickson DG, Sauvageau M, Goff L, Rinn JL, Pachter L. Differential analysis of gene regulation at transcript resolution with RNA-seq. Nat Biotechnol. 2013;31:46-53.

77. Huang DW, Sherman BT, Lempicki RA. Systematic and integrative analysis of large gene lists using DAVID bioinformatics resources. Nat Protoc. 2009;4:44-57.

78. Huang DW, Sherman BT, Lempicki RA. Bioinformatics enrichment tools: paths toward the comprehensive functional analysis of large gene lists. Nucleic Acids Res. 2009;37:1-13.

79. Ravasi T, Suzuki H, Cannistraci CV, Katayama S, Bajic VB, Tan K, Akalin A, Schmeier S, Kanamori-Katayama M, Bertin N, Carninci P, Daub CO, Forrest AR, Gough J, Grimmond S, Han JH, Hashimoto T, Hide W, Hofmann O, Kamburov A, Kaur M, Kawaji H, Kubosaki A, Lassmann T, van Nimwegen E, MacPherson CR, Ogawa C, Radovanovic A, Schwartz A, Teasdale RD, Tegner J, Lenhard B, Teichmann SA, Arakawa T, Ninomiya N, Murakami K, Tagami M,
Fukuda S, Imamura K, Kai C, Ishihara R, Kitazume Y, Kawai J, Hume DA, Ideker T, Hayashizaki Y. An atlas of combinatorial transcriptional regulation in mouse and man. Cell. 2010;140:744-52.

80. Mi H, Muruganujan A, Casagrande JT, Thomas PD. Large-scale gene function analysis with the PANTHER classification system. Nat Protoc. 2013;8: 1551-66.

81. Ginzinger DG. Gene quantification using real-time quantitative PCR: an emerging technology hits the mainstream. Exp Hematol. 2002;30:503-12.

82. Barker M, Rayens W. Partial least squares for discrimination. J Chemom. 2003;17:166-73

\section{Submit your next manuscript to BioMed Central and we will help you at every step:}

- We accept pre-submission inquiries

- Our selector tool helps you to find the most relevant journal

- We provide round the clock customer support

- Convenient online submission

- Thorough peer review

- Inclusion in PubMed and all major indexing services

- Maximum visibility for your research

Submit your manuscript at www.biomedcentral.com/submit 